Portland State University

PDXScholar

$1-1-2010$

\title{
Local food and land-use in Washington County, Oregon
}

Joshua James Cousins

Portland State University

Follow this and additional works at: https://pdxscholar.library.pdx.edu/open_access_etds Let us know how access to this document benefits you.

\section{Recommended Citation}

Cousins, Joshua James, "Local food and land-use in Washington County, Oregon" (2010). Dissertations and Theses. Paper 124.

https://doi.org/10.15760/etd.124

This Thesis is brought to you for free and open access. It has been accepted for inclusion in Dissertations and Theses by an authorized administrator of PDXScholar. Please contact us if we can make this document more accessible: pdxscholar@pdx.edu. 


\author{
Local Food and \\ Land-use in Washington County, Oregon
}

by

Joshua James Cousins

A thesis submitted in partial fulfillment of the requirements for the degree of

\author{
Master of Science \\ in \\ Geography
Thesis Committee:
Martha Works
Thomas Harvey
Hunter Shobe

\title{
Portland State University
}

2010 


\begin{abstract}
Local food networks are often defined as presenting a variety of alternative food production, consumption, and distribution practices to the conventional food system such as community-supported-agriculture, farmers markets, and community gardens. Local food initiatives are commonly proposed as a model for the future of sustainable agriculture, and in the region of Portland, Oregon the abundance of such alternative venues results from the area's natural surroundings and smart planning. The region is host to 39 farmers markets and Portland is often hailed as one of the country's most sustainable cities.

This study examines the role of local food networks in preserving agricultural land uses and livelihoods in Washington County, Oregon, a rapidly growing county adjacent to the city of Portland. I focus on small-scale agricultural landscapes where the producer sells at farmers markets or through communitysupported-agriculture (CSAs). I explore farmers' concerns about urbanization and farmland preservation, their relationship to urban markets, motives to become a farmer, engagement with the surrounding environment, and their difficulties participating in local food networks. In addition, I explore farmers market managers' insights into the development of local food networks and how they see their markets supporting small-scale farmers. In a survey of consumers I examine consumer motives to 'buy local' and consumer concerns about farmland preservation.
\end{abstract}


The research is qualitative and explores: 1) the processes shaping the development of local food networks; 2) how particular ideas and images of nature and the countryside inform both consumer desires to purchase from farmers selling locally and; 3) how those same images of nature and the countryside inform and motivate people to become farmers participating in local food networks. In so doing, I argue that the networks that sustain urban and rural systems are important in understanding the development of local food networks, and that the preservation of economically and culturally important agricultural lands in Washington County depends on a diversity of opinions and rural narratives in order to preserve smallscale sustainable farmlands close-in to cities.

The conclusion is that local food sold through alternative venues can be used as a means to preserve and develop specific and manageable farm sites and agricultural land uses but the impact is limited. Large scale impacts on agricultural land uses and livelihoods will depend on planners and advocates agreeing on policies that encompass a diversity of opinions, land uses, and land managers, while understanding the array of networks beyond the city that sustain both urban and rural systems. 


\section{ACKNOWLEDGMENTS}

I have many people to thank in the development and outcome of this project. I first want to thank the farmers who kindly shared their views and time with me and sometimes put me to work. The farmers market managers provided me with wonderful insights and advice on how to gather surveys at their markets. I am also indebted to a group of volunteers at the Hillsboro Farmers Market that enthusiastically helped me gather surveys. Martha Works is owed special thanks for helping me along the way with this project and without whom I never would have learned how to write such a project. Thanks to my other committee members, Hunter Shobe and Tom Harvey, for providing valuable insights. Finally, I want to thank all of the other geography graduate students, staff, and faculty for support, wonderful stories, and companionship throughout the project. 


\section{TABLE OF CONTENTS}

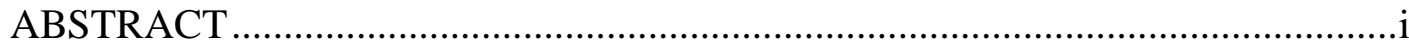

ACKNOWLEDGMENTS ….................................................................... ii

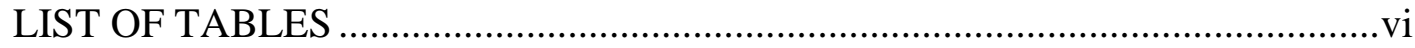

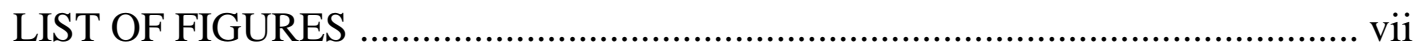

Chapter 1

EXPLAINING LOCAL FOOD AND LAND-USE..............................................

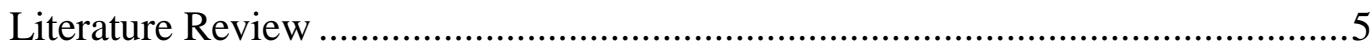

Chapter 2

STUDY REGION AND RESEARCH METHODS .............................................13

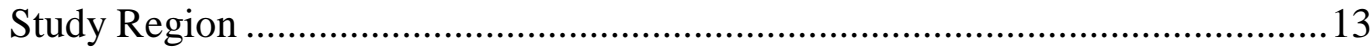

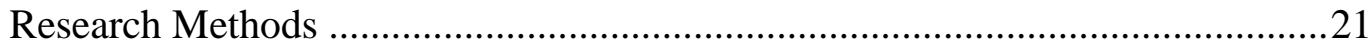

\section{Chapter 3}

UNDERSTANDING THE “GREEN CONSUMER”: RESPONSES FROM MARKET MANAGERS AND CONSUMERS ……………….............................25

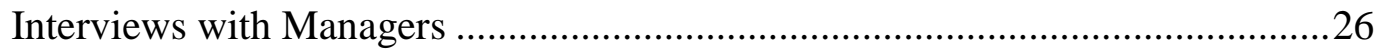

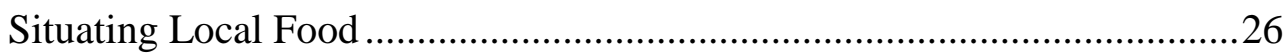

Why Go Local? Reasons to Buy Local and Identifying the "Green"

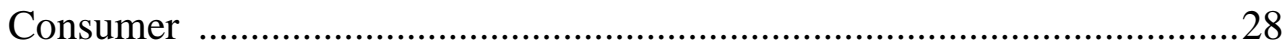

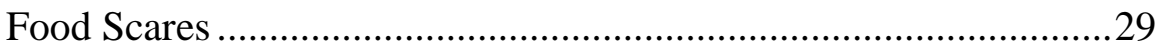

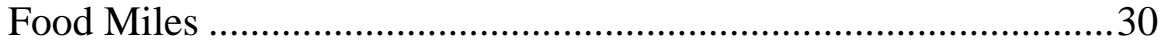

Preservation of Farmer Livelihoods and Farmlands .........................31

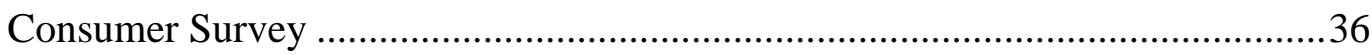


Chapter 4

NARRATIVES OF FARM LIFE: THE FAMILY FARM AND “LIFESTYLERS”

IN WASHINGTON COUNTY .....................................................................4

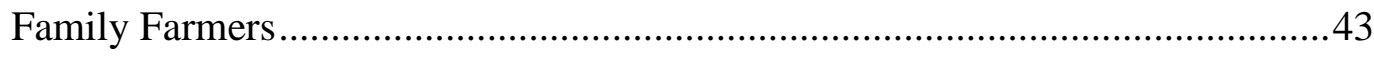

Lifestyle and Hobby Farmers ...............................................................4

\section{Chapter 5}

LAND-USE AND AMENITY PRODUCTION: THE ROLE OF CAPITAL AND

AUTHENTICITY IN SUSTAINING LOCAL FOOD NETWORKS....................54

The Role of Social and Economic Capital .....................................................56

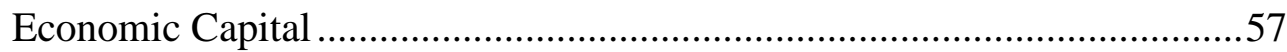

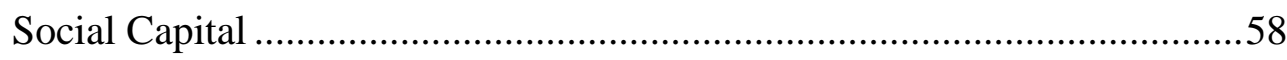

Authenticity and Creating the Countryside ....................................................61

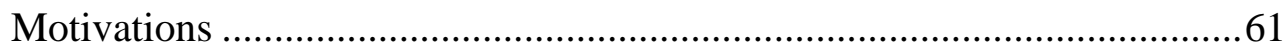

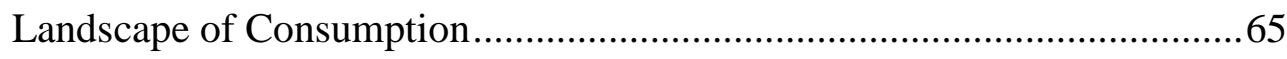

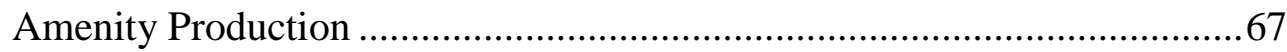

Producing Habitat and Nature .........................................................6 69

Chapter 6

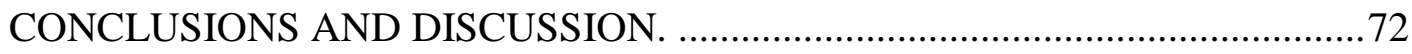

Is Food at Stake? Planning and Sustainability Conflicts ....................................74

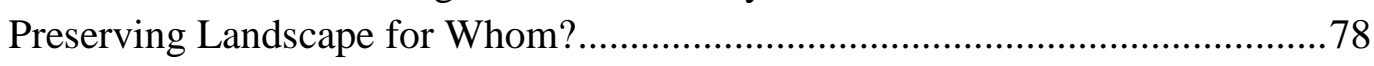

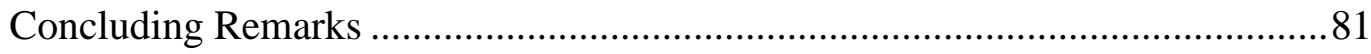

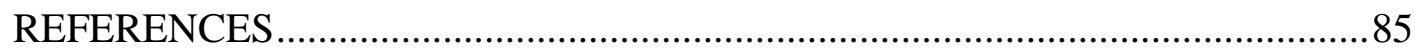

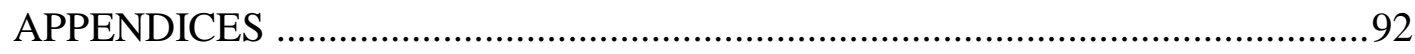

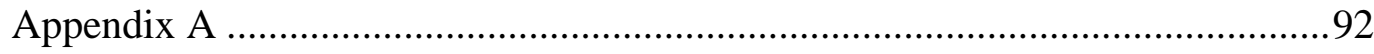

Appendix B

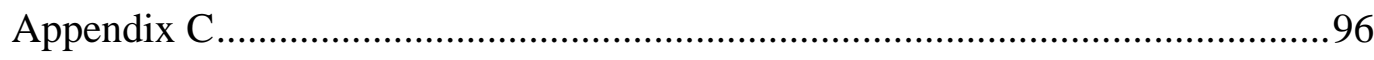

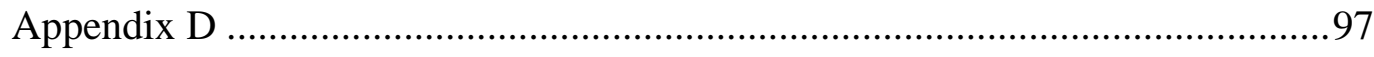


LIST OF TABLES

Table 1

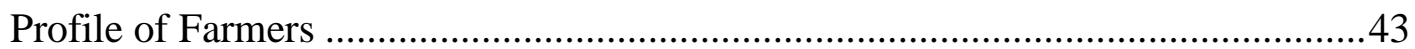


LIST OF FIGURES

Figure 1

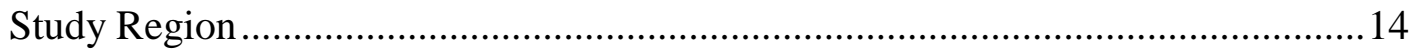

Figure 2

Population Growth in Washington County .......................................................... 16

Figure 3

Land in Farms in Washington County ........................................................ 18

Figure 4

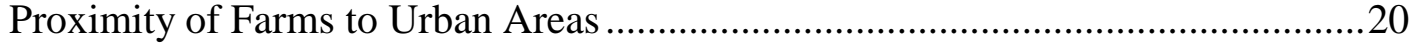




\section{CHAPTER 1}

\section{EXPLAINING LOCAL FOOD AND LAND-USE}

In the fall of 2009, I spoke with Andrew and Carol at their home. They run a community-supported-agriculture $(\mathrm{CSA})^{1}$ farm on their property not far from the Portland metropolitan Urban Growth Boundary (UGB), a state mandated boundary between the urban and rural land for all Oregon cities. During my visit they told me about their experiences selling locally, but mostly about their problems with urban growth and how they hope consumer interest in buying local can help save farms like theirs from an expanding UGB.

I think CSAs, in addition to producing extremely fresh food, helps rekindle an interest in being close to the land and an interest in where food is grown. CSAs bring people together and kindles peoples interest in farming, food production, and farm preservation... I think CSAs are helping to protect small farms [from urbanization], it's not a fad, and it's a movement that we have seen as people become more aware about where their food comes from... But our biggest concern is about urbanization of farmlands... [and] it's very short sighted.

The issue for these two farmers, and many others, is that urbanization could take up prime farmland that is valued for its cultural, aesthetic, and economic importance. This urban-rural divide is a site for small-scale sustainable agriculture where farmers, like Andrew and Carol, who sell through CSAs and farmers markets, make a living. As more population growth continues in the county many

${ }^{1}$ Community-supported-agriculture (CSA) is a system where consumers pay a fee to the farmer at the beginning of the growing season in exchange for a weekly share of the farm's products throughout the growing season. 
people within the local food movement want to see more land available for the growing CSA industry through the implementation of rural reserves, a land use designation meant to provide long-term protection for agriculture, forestry and important natural landscape features from the perceived risk of urbanization. On the other hand, the county wants to attract more high profile industries and bring more economic development to the region. To do so, the county wants to see more land set aside for urban reserves, the land where the UGB will be expanded to accommodate further growth. The main conflicts rise up where prime farmland is the most easily developable land.

Conflicts are already emerging as urban-rural line blurs in Washington County. Eric Mortenson (2009) reported in The Oregonian the fate of Lyle Spiesschaert, a third generation farmer, who has about half of his farm within the UGB. In the article, Lyle recounts how five years ago there were no new houses around his farm and now he receives complaints from his new neighbors about his farm activities. As Lyle sees more of his land-base disappear, he predicts that commodity farms such as his will need to transition to niche markets to be sold locally

Through people's food choices is one method farmers hope they can gain support for more rural reserves. Farmers hope that as people become more aware about farm issues and become connected to the land through their purchases, consumers will become vocal in local farm preservation initiatives that can help save the family farm and make small-scale operations selling in alternative venues 
viable. In this study, I examine the role of local food networks in preserving agricultural land uses and livelihoods in Washington County, Oregon.

My central questions are as follows: How is local defined and socially constructed? Why do people decide to shop locally? How do ideas of nature and the countryside inform consumer desires to purchase from farmers selling locally? How do those same images of nature and the countryside inform and motivate people to become farmers participating in local food networks? How do ideas about nature and countryside have implications for planning processes at the urban and regional scales?

My research focuses on small scale agricultural land uses where the producer sells at farmers markets or through a CSA to better understand how selling locally can help preserve agricultural land uses from urbanization. I explore farmers' concerns about urbanization and farmland preservation, their relationship to urban markets, motives to become a farmer, engagement with the surrounding environment, and their difficulties participating in local food networks. In addition, I explore farmers market managers' insights into the development of local food networks and how they see their markets supporting small scale farmers. Complementary to the interviews is a survey where I examine consumer motives to 'buy local' and consumer concerns about farmland preservation. Interpretive frameworks drawn from political ecology, rural studies, and landscape are used to analyze the role of particular ideas and imaginaries of the rural countryside in supporting agricultural livelihoods and preserving agricultural lands. 
Although my case study occurs in its own geographical and historical context, CSAs and farmers markets are proliferating across the country and landuse conflicts are especially common across many parts of the West. The motivations for shopping locally and the impetus for landscape preservation may be different in different parts of the country, but they have in common environmentalist concerns and ideas about nature and health, getting back to the land, and desires to simultaneously live in and preserve the landscape. I argue that the networks that sustain urban and rural systems are important in understanding the development of local food networks, and that the preservation of economically and culturally important agricultural lands in Washington County is dependent upon a recognition of the diversity of opinions urban and rural interests in order to preserve small-scale sustainable farmlands close-in to cities. The opposing land use categories of urban and rural are used to specify permitted land use activities, but do not recognize motivations of farmers who desire to live in and work in the landscapes near urban centers, nor their challenges participating in a local food network. A variety of farmers and consumers participate in local food networks and are involved in giving meaning to local food and landscape. However, without asking whose landscape is being protected for what purpose, or who gets to participate in the construction of local food and landscape, or what it means to protect the rural countryside, desires for sustainability in the Portland metropolitan area could become "another dream of impossible fulfillment, creating ironies, and inequalities in its effects" (DuPuis 2006, 130). 


\section{Literature Review}

The production and consumption of food is a basic need to support everyday life. Increasingly, the sites of food production are hidden from view of most consumers. People know little about where their food comes from, nor the people who produce it, and are faced with headlines of food scares, peak oil, labor exploitation in food production, and the pressure unsustainable agricultural practices are putting on natural systems. In part, such concerns and a 'faceless' and 'placeless' food system have been major drivers in the development of local food networks as people seek out to 'know their farmer' or in some instances become farmers themselves.

A relocalization of food started to gain prominence in the 1960s with the practice of 'fair trade,' back to the land movements, the rise of health food stores, and the emergence of community supported agriculture (CSA). The roots of the 1960s alternative food movements come from J.I. Rodale and the Rodale Press who began publishing Organic Gardening in 1942, a magazine that emphasized production of 'natural' and 'whole' foods and the relationships between the health of soil, quality of food, and human health (Vos 2000; Guthman 2004). However, as Vos (2000) notes, during this time food movements, such as organic, became a visible social movement and response to the highly industrialized food system and banality of consumerism that manifested itself in the back to the land movement. In California, the 'counter-cuisine' and chefs such as Alice Waters of Chez Panisse also began to feature fresh, seasonal ingredients, sourced from local farms (Starr et 
al. 2003; Guthman 2004). CSAs also originated in the 1960s--beginning with the name "farming with a face on it" in Japan--with the goal to link urban families to the seasonality of food production and farm life (Starr et al. 2003, 302).

Local food networks, from their origins then, are considered to be left of the political center, and are generally regarded as being based on a progressive political agenda that relies upon the political willingness and social agency of individuals and institutions to establish more sustainable food systems (Whatmore and Thorne 1997; Trauger 2009). Current research investigates a number of questions about the social relations, emergence, and development of local or alternative food networks, and the processes sustaining them (Hinrichs 2000; Jarosz 2000; BlayPalmer and Donald 2006). Using the idea of tectonics as a metaphor to investigate the "shifting of plates" in the agrifood system, Allen et al. (2003) investigated alternative food initiatives in California to suggest the importance of understanding the differences and successes of such initiatives in achieving their goals of environmental sustainability, economic viability, and social justice. Further research has shown, however, that some alternative food systems have proven stronger than others in addressing their stated goals, and it is probable that local food networks "exist along a spectrum from weaker to stronger" (Watts, Ilbery, and Maye 2005, 27).

Local food movements emphasize concepts such as social embeddedness, trust, and place, and are central to understanding the quality "turn" in food practices (Goodman 2003). Direct markets that can provide consumers with the opportunity 
to engage in face-to-face relationships with their farmer and build community ideals based on caring, represent an alternative to industrialized systems of food production. As with organic farming, however, which has been shown to have been taken over by the same industrial and globalized food systems it set out to oppose (Pollan 2001; Guthman 2004), local may not live up to the discourses that suggest it is a more just system of food production. Social inequalities can exist in local food systems just as they can in globalized food systems, and the assumption that local food networks are inherently better "conflates spatial relations with social relations" (Hinrichs 2000, 301).

Other research has also begun to look more closely at the various ways place is given meaning in local food systems (Feagan 2007; Blake, Mellor, and Crane 2010). A local food system is to be understood as "rooted in particular places, aim to be economically viable for farmers and consumers, use ecologically sound production and distribution practices, and enhance social equity and democracy for all members of the community" (Feenstra 1997, 28). Local food systems can then be seen as a means for transformative place-based politics, contingent upon a recognition of a plurality localities (Feagan 2007, 38-39).

Nonetheless, CSAs and farmers markets are proliferating as a growing number of people want to "know their farmer" or to "know where their food comes from." The popularity of recent literature on food such as Michael Pollan's The Omnivore's Dilemma (2006), Barbara Kingsolver's Animal Vegetable Miracle (2007), and Eric Schlosser's Fast Food Nation (2001) that advocate the worthy 
principles of eating local seasonal foods rather than fast food speaks to the growing local food movements across the country. These readings have convinced many people and activists to participate in local food movements and to believe that their food choices can have a transformative impact on local food politics. Drawing from the bioregionalism idea of a watershed and applying it to food, Kloppenburg et al. (1996) suggest that recognizing oneself within a foodshed can reconnect people to their locality and create a sense of responsibility; this sense of responsibility can help shape what the landscape may look like and possibly influence people to preserve the small-scale farm.

Moreover, responsibility often translates into community partnerships and the promotion of farming as a method for social and health improvement. As Guthman (2008) points out, projects such as farm-to-school programs, are usually marketed on the idea that it will improve the health of the school children and are used to empower citizenship among participants. She further notes that these ideals are carried over by the consumer and asks for a "politics of the possible" to examine the micro-politics that shape various alternative food initiatives. Related, is Goodman and Dupuis' (2005) argument that local small scale and organic agriculture does not necessarily mean a more just food system. Rather they ask for "reflexive" food initiatives where decisions about local food systems come about democratically and are not "unreflexive" in denying local political processes. They show the need to understand that local does not translate to a more just system, but that the local politics framing food networks are often imperfect political processes 
embedded in broader global and regional processes. Jarosz (2008) uses this framework in her study of alternative food networks in Skagit and King counties in Washington to argue that both urban and rural contexts are important in the development of alternative and local food networks.

My study of local food networks in Washington County follows a similar logic to better understand urban-rural relations and the ways in which producers and consumers unite in a particular place. My examination, however, also builds on the theme of the exalted status and romanticized nature of agricultural landscapes and farming in the American psyche by investigating farmer and consumer motivations to shop locally. Insights drawn from political ecology about conservation and control and environmental conflict in the context of urban and "first world" settings -- particularly in the American West -- about who has access and control over the landscape frame this study (McCarthy 2002; Walker and Fortmann 2003; Robbins 2004; Heynen, Kaika, and Swyngedouw 2006). Particular visions of the landscape and rural life inform production practices that not only produce fresh seasonal produce for the consumption of an advantaged urban clientele, but also produce a landscape that is consumed for its aesthetic beauty. William Cronon's (1991) work on the growth and development of Chicago is one of the more prominent stories linking rural processes to urban processes. His analysis demonstrates that if what happens in the countryside is inextricably linked to the city, the division between city and country is nothing but a false dichotomy. Urban desires to experience the pastoral or urban desires to engage with their 
farmer through these networks can be seen as having the possible effect of transforming the countryside, but also connecting the rural to the urban through consumption practices. This underlying unity between Portland and its countryside demonstrates-on a smaller scale than Chicago and the great west-that city and country are not opposite one another. In addition to this underlying link, it is important to understand how people decide to become farmers living in exurban areas, consumer motivations to participate in local food networks, and what this might look like on the landscape (particularly with regard to renewed interest in sustainable cities).

Research on people's motivations and desires to move to the countryside are numerous and suggest that most move to the countryside for the restorative aspects that 'rural nature' may offer. Many migrants to rural areas come from the city seeking refuge in a more natural place to escape a more industrial landscape and seek the "good life" in an idealized pastoral setting. As Cadieux (2006) suggests, these landscapes become invested with environmental aspirations of residents who attempt to fulfill their ideals of the rural idyll by inhabiting exurbia through the appropriation of aesthetically productive landscapes but also by amenity production.

Consumer desires to engage with local food networks can also be informed by pastoral images, what Michael Pollan (2001) terms the "supermarket pastoral." He uses the term to describe how big business uses the word organic to conjure up a whole story about how food is produced through the pastoral images associated 
with organic agriculture. People attending farmers markets are going beyond the supermarket pastoral to connect with a farmer, but are applying many of the same pastoral images to their purchases. As one of the market mangers I interviewed for this research pointed out when describing the customers at her market: "These are the Whole Foods shoppers. They generally are not buying processed foods. They don't eat fast food as general rule. They want local. They want fresh." The manager goes on to describe how many of the shoppers are looking for the story behind their food and that the market does that by connecting the consumer to the farmer.

The pastoral images that can influence consumer behaviors are also related to trends in alternative, sustainable, or green consumption. Gilg et al. (2005) points out three sets of variables that are influential in categorizing a green consumer: environmental values and concern, socio-demographic variables, and psychological factors. The issues that affect the variables of green consumption show that people, as part of a move towards new lifestyles, are engaging with sustainability in varied ways that incorporate purchase and habitual related elements such as riding bicycle to work. More importantly, the pastoral images influencing consumer behaviors are part of a process of edenic myth-making in conservation seeking consumers (Bryant and Goodman 2004). Bryant and Goodman (2004) demonstrate how the process of edenic myth-making occurs with reference to cultural images such as wilderness, or in the case of my study, the family farm, to enable the consumer to connect to nature. 
The consumption of rural life can have important policy implications as well. Hinrichs (1996), for example, by interpreting rurality as an amalgam of landscape, tradition, and place, demonstrates how a construction of rural landscapes is promoted by state authorities in a way that fits idealized images of rurality for the consumption of tourists. Such a construction of rurality, she argues, has in part led the National Trust for Historic Preservation to designate the entire state of Vermont as an endangered historic place and the banning of all billboards, but also fueled a development boom not welcome by all. The marketing of rural life does not benefit everyone equally nor does it allow many of the most disadvantaged to make a living from the promotion of Vermont as a distinct rural place (Hinrichs 1996).

Constructions of nature can also have important policy and consumer implications. Huber and Currie (2007) asked how an urban social construction of nature becomes politically and economically powerful in the production of space and nature both inside and outside the city of Portland, Oregon, and how urban imaginaries of nature mobilize regional governance regimes. The UGB is one such example: it frames Portland as a thriving city adjacent to prosperous farmland. Portland, through people's consumption practices is a place where "local produce becomes a commodified medium through which Portlander's [sic] can buy the results of the UGB - agricultural landscapes protected from the rising tide of sprawl" (Huber and Currie 2007, 723). These food consumption practices offer commodified versions of the urban imaginary of nature, which can be a way of buying landscapes, linking rural and urban. 


\section{CHAPTER 2}

\section{STUDY REGION AND METHODS}

\section{Study Region}

Washington County, in many respects, presents an ideal location for studying local food networks and land-use preservation. The rapidly growing county located adjacent to Portland, Oregon, is home to over a half-a-million people with projections of more growth. Beginning in the mid 1950s, sub-division and commercial expansion coupled with a $71 \%$ increase in population during the 1960s reduced the agricultural base in the region by $20 \%$ by 1965 (Robbins 2004). Such rapid growth and farm loss provided the context for concerns about urban growth and farmland preservation in the state. This section describes the processes of urbanization that set the conditions for the present land-use politics in Washington County and the Portland region.

In Washington County, as well as other parts of Oregon, urbanization has been an important process shaping the county since the 1950 s. The county population grew as a suburban community as a result of its proximity to Portland, and because of its success in attracting high-tech industries. From the 1950s into the 1970s Tektronix was the core of the high-tech industry in Washington County, but in 1976 Intel chose the area for a major branch (Abbott 2001). Soon after, other companies followed such as, Hewlett-Packard (1979), Wacker Siltronics 


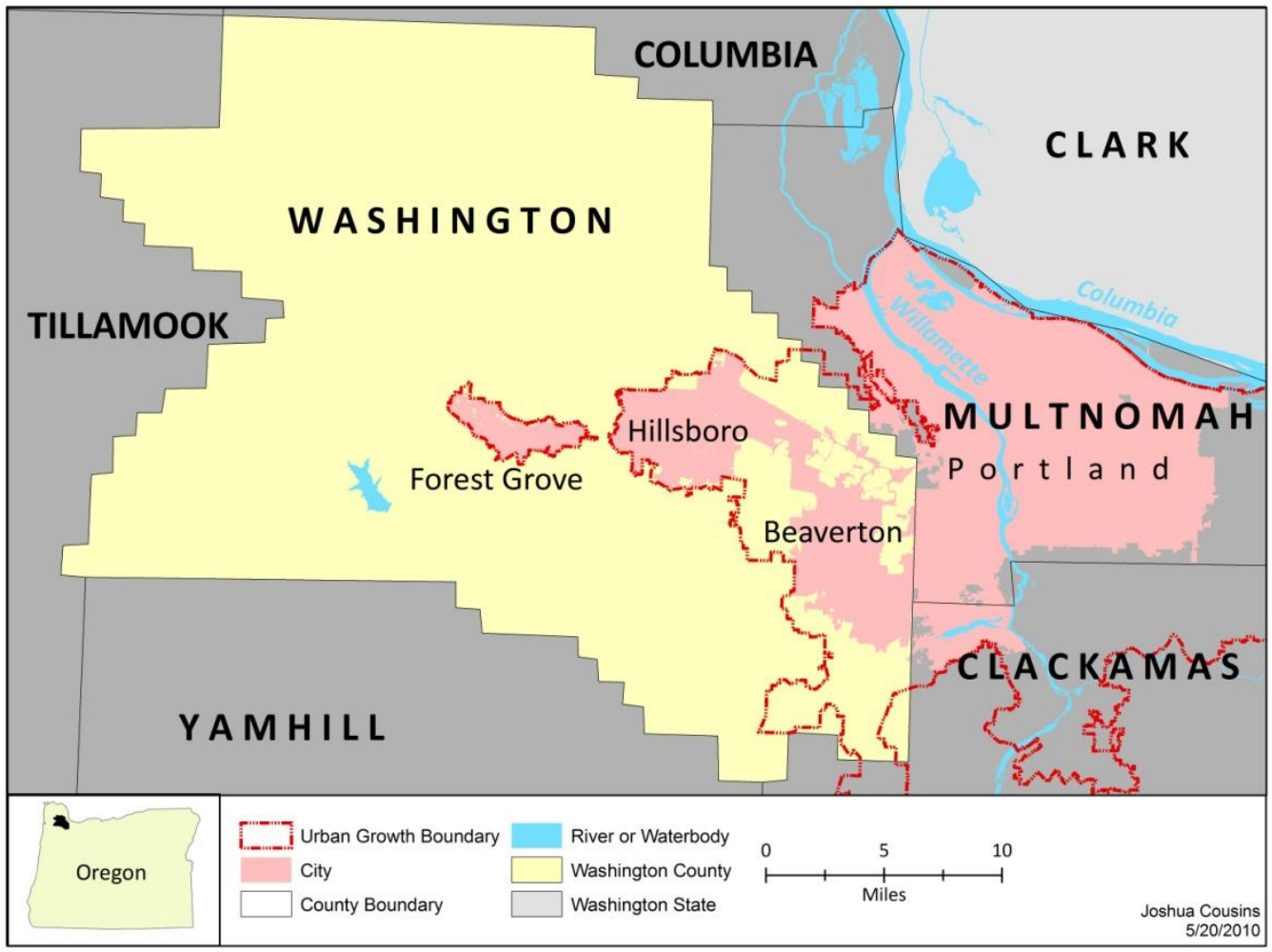

Figure 1. Washington County, Oregon.

(1980), and Sharp, Epson, and NEC through the 1980s. Such success in bringing in high-tech industries gave the region its nickname as the 'Silicon Forest.' The addition of other large companies' headquarters in the county such as Nike and recently Colombia Sportswear also fueled population growth. It is within this context of urban growth that the Portland metropolitan region established a statemandated urban growth boundary (UGB) in 1979 to protect farm and forest lands from urbanization. The Portland region's UGB is administered by Metro, a regional planning agency created in 1979 to develop and administer the statemandated land use laws and encompasses parts of Washington, Multnomah, and Clackamas counties. 
The origins of the UGB date back to the 1960s when environmentalism was gaining momentum and works such as Rachel Carson's Silent Spring (1962) were influencing policy makers across the country to enact measures that supported environmentalists concerns about personal and environmental health (Huber and Currie 2007). The passage of Senate Bill 10 in 1969 was Oregon's first move towards mandating local and county governments to adopt comprehensive planning and zoning ordinances (Robbins 2004). The most important of the early efforts came in 1973 when Senate Bill 100 passed and required all Oregon cities to establish urban growth boundaries, as well as land use designations such as exclusive agricultural and forest use to protect farmland and open spaces from urban development, and created the Land Conservation and Development Commission (LCDC) as a bureaucratic mechanism to oversee local and statewide land use, conservation, preservation, and development goals (Abbott 2001; Harvey and Works 2002; Huber and Currie 2007). Oregon is not unique in establishing urban growth boundaries and "right to farm" laws, but the state is unique in the fact that local governments are required to integrate these through land use planning (Knapp and Nelson 1992, 157).

Furthermore, Senate Bill 100 elicited an imaginary of nature that not only considered an aesthetic value of open and green spaces, but more specifically, focused on nature as the resource constituting the very means of producing Oregonian livelihood and continued prosperity (Huber and Currie 2007, 714). The urban growth boundary became a cultural icon used to describe or communicate 
images of prosperous farmland next to a thriving city through artists' depictions, the media, and through people's daily conversations (Abbott and Margheim 2008).

The population of Washington County increased $19.8 \%$ between April 1, 2000 and July 1, 2009 to 537,318 people (US Census 2009), and by 2030 another 280,000 residents are expected to be living in the county (Suh 2007) (Figure 2). Continued growth in the county has put pressures on communities to expand the urban growth boundary through the designation of urban and rural reserves. The process for designating urban and rural reserves was created through the passage of Senate Bill 1011 by the Oregon legislature in 2007 as part of a broader regional strategy on how to accommodate future growth and protect the region's natural resources. The bill provides a means for protecting farms, forests, and natural landscape features, such as wetlands, from urbanization for the next 40-50 years. Senate Bill 1011 also provides a process for a diverse group of individuals and interests such as farmers, developers, local governments, and advocacy groups to make recommendations for urban and rural reserves.

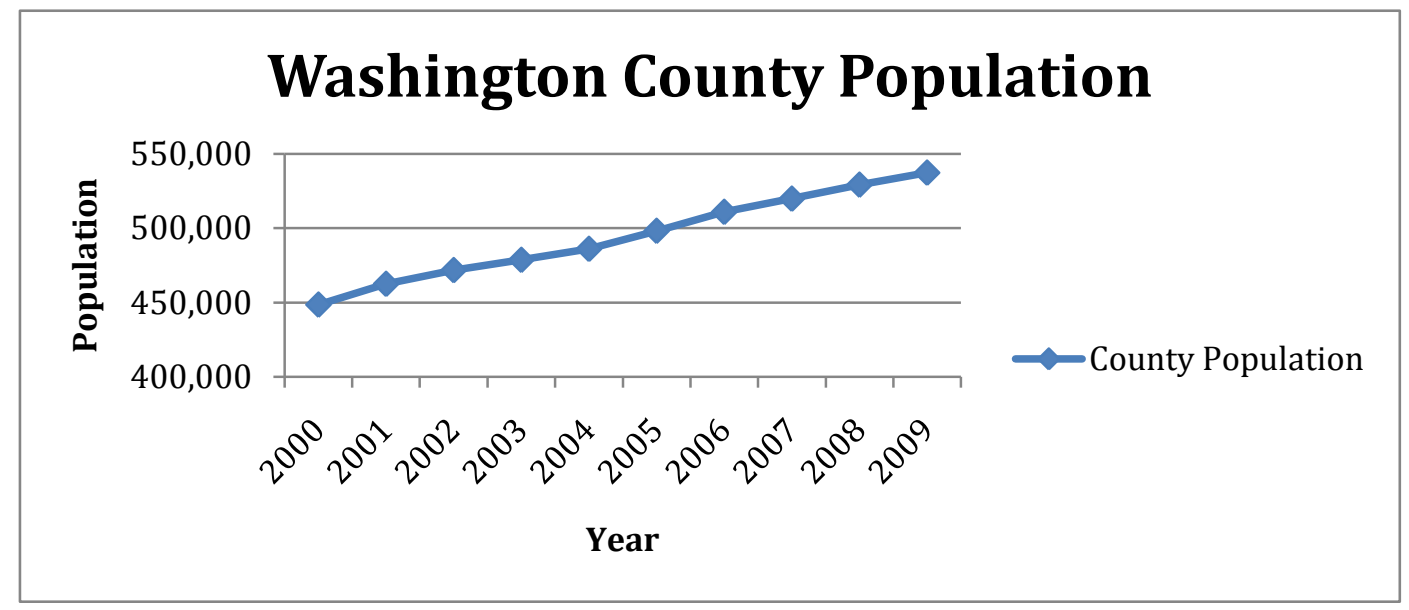

Figure 2. Population Growth in Washington County, 2000-2009, US Census 2009. 
In a county as economically diverse as Washington County, where agricultural sales rank $5^{\text {th }}$ in the state, and several large companies have facilities or headquarters, visions of Washington County's future are mixed. Visions of the county's future land use are split over desires to continue to grow and attract high profile companies, and pressures to preserve agricultural lands for economic, environmental, cultural, and social reasons. Unfortunately, most of the best agricultural lands are also some of the most desirable for developers. As Travis points out, "the region's political-economic regime tends to support...in general, land development over land preservation" $(2007,65)$. In Washington County the comment holds true. Most of the steering committee members designating urban and rural reserves represent cities and urban economies, not rural economies. Ultimately this process comes down to whose vision of the landscape will prevail in the process of designating urban and rural reserves.

As a result, Washington County has proposed twice as much land for urban reserves as nearby Multnomah and Clackamas counties combined (Schmidt and Suh, 2009). The large designation of urban reserves highlights the contradictions and uneven power relations between city and country that Washington County is faced with--whether to preserve farmlands for economic, social, and ecological reasons, or to pursue development with the hopes of attracting more high profile industries to cities. 
Agricultural Profile

Changes in farmland can help provide further context about concerns over farm loss. In Oregon the land in farms and number of farms has decreased $4 \%$ between 2002 and 2007 along with a slight decrease of .5\% in the average size of farms over the same period. Washington County has experienced a similar trend over the same period with a $2 \%$ decrease in land in farms (Figure 3), a $7 \%$ decrease in number of farms, but a $6 \%$ growth in the average size of farms. Like most of the Willamette Valley, Washington County grows a diverse set of agricultural products rather than commodity crops. Washington County ranks high in the production of blueberries, hazelnuts, nursery products, dairy, grass seed, wine grapes, and other crops. The basis for much of the productivity in Washington County is the agricultural land base or the soil. 127,984 acres Washington County is in farmland with 86,632 acres classified as prime farmland, $7 \%$ of the state total. In order for

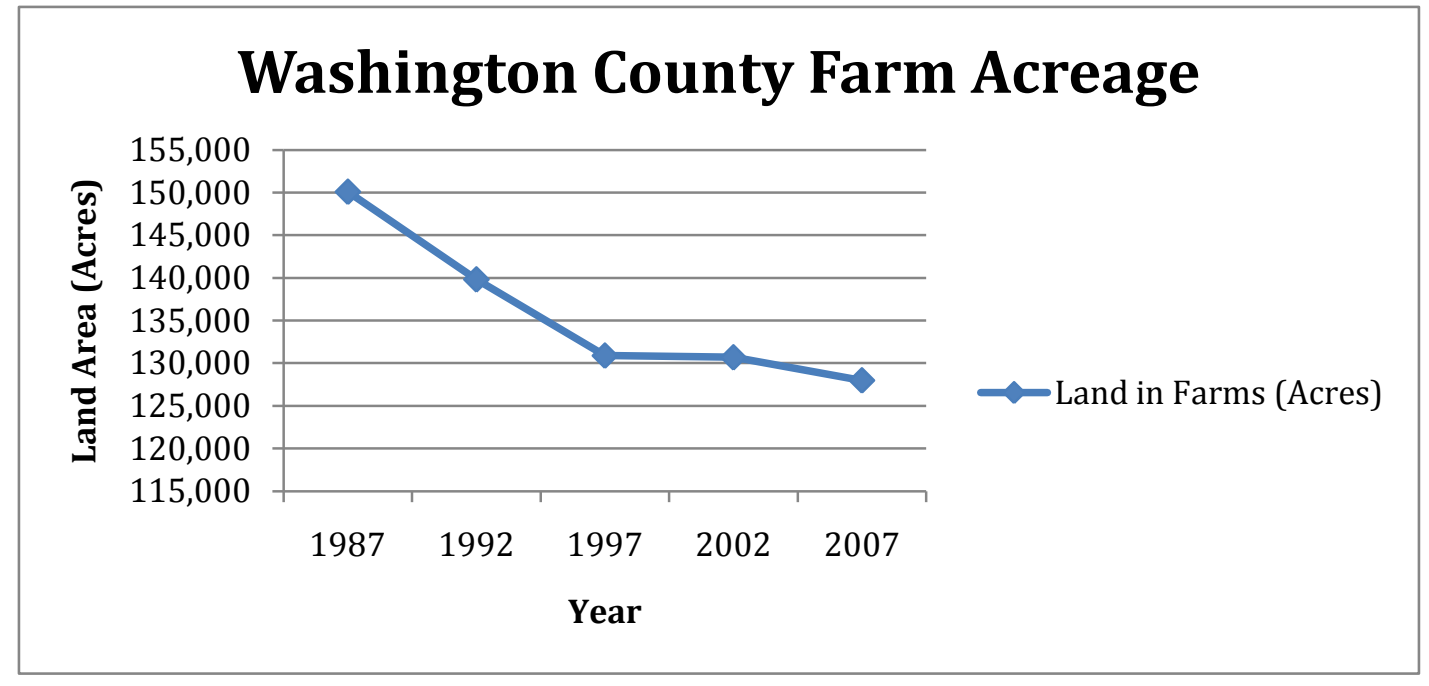

Figure 3. Land in Farms in Washington County, 1987-2007, USDA NASS 2007. 
Washington County's agricultural base to remain economically viable it is important that farmlands be preserved and to develop creative ways to sustain urban growth and farm production with close-in relationships to the city.

Urban oriented agriculture such as CSAs and small scale farms selling at local farmers markets can serve as one mechanism for preserving productive agricultural lands. Many of the farmers who cultivate for a local market rely on the fact that they are protected from urbanization by a growth boundary. However, that is not the case with all farms. Some farms inside the UGB rely upon the willingness of individuals to preserve farms in urban areas through reduced rents or agreements to keep land in production. Nonetheless, of the farms in Washington County selling at farmers markets or through CSAs, the average distance to the current urban growth boundary is 1.9 miles (Figure 3). The expansion of the UGB poses a threat to farmers who depend on as proximate a location as possible to urban locations to sell their goods and may be forced further from urban areas if the UGB is expanded.

The demand for local and organic food from a growing urban population helped lead to the creation of a number of farmers markets in Washington County. The largest market is the Beaverton market that opened in June of 1988 with only 12 vendors and today hosts over 100 vendors and attracts thousands of people weekly to the market. The Hillsboro market, although not large as the Beaverton Market, began in 1987. The newest market in the county is the Forest Grove market which opened in 2005 and is managed by Adelante Mujeres, a non-profit 


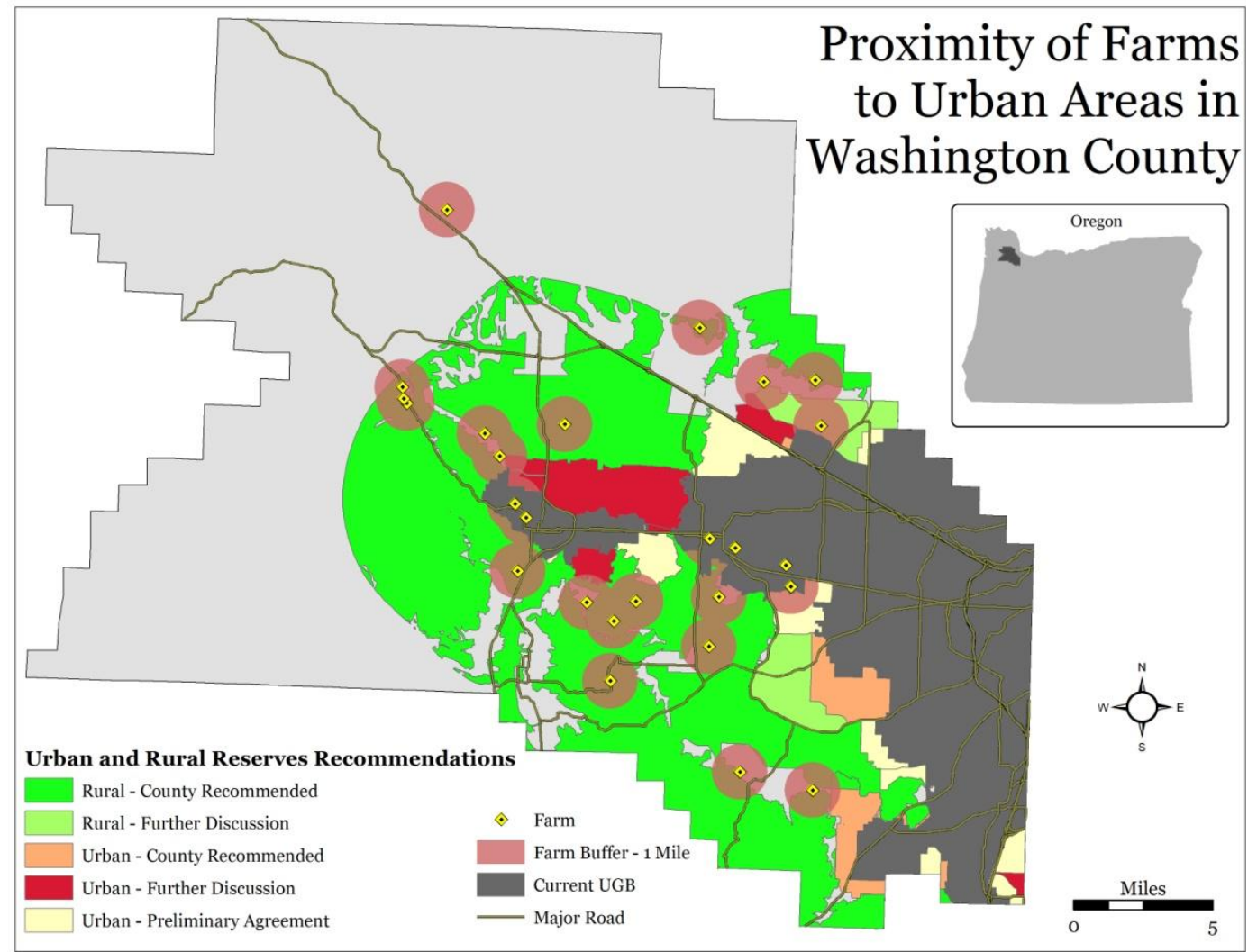

Figure 4. Farms listed in Portland CSA Coalition and farm vendors listed in the Forest Grove, Beaverton, and Hillsboro farmers market directories farming in Washington County.

group that focuses on empowering Latina women and works as a micro enterprise for immigrant families.

CSAs also play a significant role providing food for an urban population.

The growth in CSAs increased dramatically over the last couple decades with 12,549 CSA farms now operating in the United States and 311 in the State of Oregon (USDA 2007). Forty-six CSA farms are now operating in the Portland area, 9 of which are in Washington County. Of the CSA farms where I conducted interviews all are working at full capacity with wait lists. In fact, all CSA farmers interviewed said they did not need to advertise to attract customers and one farmer came to be a CSA farmer because she could not find one and saw a new business 
opportunity. The dramatic growth in this sector of direct marketing is very important to understand as it could have a significant impact on the agricultural landscape.

Alternative food initiatives, such as CSAs, emerge where a number of farmers work to provide a demand for local produce and are dedicated to seeing their farm and similar farms flourish in the area. Many farmers begin local production or CSAs with high environmental aspirations to be stewards of the land and begin to replant native vegetation in order to restore native ecologies and attempt to "farm in nature's image." Those land use practices are important to understand how their land uses could help restore degraded agricultural plots, provide food for a nearby population, and represent a "greening" of the urban fringe. A better understanding of how local food networks can transform and impact the landscape, especially in exurban areas, can provide insight into ways to better plan for growth and sustainable communities.

\section{Research Methods}

The research methods used qualitative methods and data to better understand the role of local food networks in preserving agricultural lands and livelihoods in Washington County. I interviewed farmers and farmers market managers, and conducted consumer surveys at three farmers markets in order to gain a number of perspectives about urbanization and farmland preservation, urbanrural relations, and insights into local food. 
I selected participants based on their involvement in farmers markets and CSAs. The farmers market managers were chosen because they manage the most prominent farmers markets in the county. My selection of farmers was drawn from listings in the farmers market directories and from the Portland CSA Coalition. From these lists I compiled a spreadsheet of 30 farmers participating in local food networks in Washington County. I contacted 18 farmers and interviewed 7 (23\% of the study population). My consumer survey participants were canvassed at three farmers markets with 79 collected surveys.

The interviews with farmers (Appendix A) assess land use practices and their associated narratives to understand how they frame their operation with respect to:

1) Urban growth.

2) Their connection to land use issues at local, regional, and global scale issues.

3) Their farming history and philosophy.

4) The benefits and challenges of selling in local food networks

5) Their experience with local food networks.

My interviews with farmers began with a set of questions to understand how they frame their farm and associated land uses with respect to urban processes and their role in transforming the landscape. I was looking for narratives about urbanization onto farmland, conflicts that may have arisen between urban residents and farmers, their land practices, and concerns and difficulties. Although the interviews varied greatly in terms of both length (30 minutes -3 hours) and the questions asked, they all followed a similar format. All interviews were recorded with a digital voice recorder and conducted on site. The interviews began with a brief explanation of 
my study and a little about myself. I then asked the farmers to fill out a short survey (Appendix B). Afterwards, I asked a set of questions that I asked all farmers, beginning with, "what does a local food system mean to you?" After the set of questions, I asked the farmers to take me around their farm to show me particular projects and "what they're doing with their land." This part of the interview allowed the farmers to point to significant things being done with the landscape and for me to ask questions about features of their farm. I could further understand farmers' motives and intentions with these activities by being able to record specific land uses, such as planting flowers between the crops or how they try to combine both productive and amenity uses on the property.

In addition, I examined the opinions of farmers market managers to gain particular insights about the emergence and development of local food networks. Market manager interviews (Appendix C) took place at their market offices and lasted between 20 minutes and 45 minutes in length. The questions varied slightly from interview to interview, but all were asked a set of the same questions in roughly the same order. The market manager interviews also began with the same question asked the farmers and progressed towards more politically charged questions as the interviewee became more comfortable. At the conclusion of these interviews I also asked the managers to address any particular concerns they have about urbanization and farmland and what they believed to be the most important component of local food systems. 
The interviews are complemented by a consumer survey (Appendix D) that sought to understand consumer motivations to participate in local food networks and the role they may have in preserving agricultural lands and livelihoods. The surveys took place at three different farmers markets in Washington County. At the Forest Grove and Beaverton markets, the canvassing was done only by the researcher, and at the Hillsboro survey was conducted with the help of market volunteers. Recruitment for survey subjects was self-selected. Survey subjects were selected based on their attendance at the market and their willingness to spend the time needed to take the survey.

For each of the interviews I borrowed from the grounded-theory approach (Glaser and Strauss 1967) to identify important themes. I transcribed the interviews and made note of the most important themes to emerge from the interviews. The format of the interviews does not lend itself to a statistical analysis. Rather the narratives were compiled to create a list of key themes in order to induce a framework for the study. I further coded the consumer survey results to create descriptive statistics. 


\section{CHAPTER 3}

\section{UNDERSTANDING THE “GREEN CONSUMER”: RESPONSES FROM MARKET MANAGERS AND CONSUMERS}

People frame their decisions to purchase local from a wide range of issues and standpoints. This chapter discusses the results of interviews with farmers market managers and surveys of consumers at three farmers markets, where I explore the range of topics and perspectives from which people decide to buy local. The results suggest ideas of sustainability are acted out at the markets as a means to indirectly link the customer "back to the land" through their consumption practices. The consumption practices are part of a larger trend toward "ethical eating" and "sustainable consumption" that emphasizes consumer knowledge and individual responsibility. However, it is through these consumption practices that the social bonds of community and trust often used to describe local food networks are forged, and opportunities arise for the consumption of local food to play a role in the preservation of the small-scale farm. The narratives of the farmers market managers provide insight into the difficulties of defining a local food system and consumers" "green" or "sustainable" consumption decisions for purchasing local. The survey results provide additional understanding into consumer motivations for purchasing local. 


\section{Interviews with Market Managers}

Between September 15, 2009 and September 25, 2009 I conducted four interviews with farmers market managers to better understand their insights about local food, the development of local food networks, and how they see their markets supporting small-scale farmers. The interviews suggest that managers contextualize their markets based on a broad set of processes and factors. The managers see their markets as an important way to support local farmers and the local economy, build community, and provide an alternative to the industrialized food system. This section focuses on how the market provides the place and experience for consumers to act on a number of issues and how those actions can help preserve small-scale farming operations participating in local food networks.

\section{Situating Local Food}

In order to maintain integrity at the markets the market managers need to define what a local food system is for the purpose of their market and what type of vendors can be at the markets based on a geographic location and types of products sold. The managers identify with the bioregionalist idea of a foodshed to define local food systems. The foodshed concept is meant to give consumers and managers a region bounded by natural features, akin to a watershed, to understand the scale to establish a local food system. The managers identify the Pacific Northwest, sometimes including Northern California, as the appropriate scale to 
establish a local food system within a metropolitan context. For their markets, however, the definition is often limited to just the state and southwest Washington. The definition is still ambiguous as one market manager's comments suggested when discussing local food:

For me local food is a regional thing, the Pacific Northwest. I would include Northern California in that because that is more realistic. I think it is best to try and include as many people as possible in the local food movement and to do that I define it as the region. For our markets we define it as Oregon and southwest Washington, which we don't define (M4).

The managers would agree that it would be ideal to have a localized food system where everyone can eat fresh seasonal food grown close to home and "know their farmer," but understand that it is not always realistic, nor practical, in all cases. They recognize that food production is a global market and that an efficient food system that can move large quantities of food around the country and world can be beneficial:

It's such a global market and people want foods that don't grow in their region, myself included... It's important we buy locally and support farmers in the area as much as we can. Then the coffee, olive oil, and bananas can be [brought in from] outside [the region] (M4).

Think about natural disasters, Katrina, or something like that. If that economy was solely [sustained by] local food it would be completely out of luck. The chain grocery stores or networked grocery stores are a part of our national infrastructure, but local food movements are a nice complement to that (M1). 
Why Go Local? Reasons to Buy Local and Identifying the "Green" Consumer

According to farmers market managers there are several reasons why consumers shop at farmers markets. Managers express consumer concerns about the negative impacts of the conventional food provisioning system which include health, environmental impacts, food miles, the "sterile" experience of shopping in chain grocery stores, and the decline of the small-scale family farmer as reasons why people attend farmers markets. The consumers who act on those issues can be defined as "green" consumers who base their purchases on a concern for social and environmental well being. According to the managers those consumer concerns are often resolved at the farmers market through consumer choice and agency. The markets provide an alternative venue that builds on the social bonds of community and trust, but also seeks to sell an authentic experience for consumers trying to settle any concerns they might have about food purchases and who seek part of the farm experience. The resulting consumption practices provide the context for how consumer purchases can help preserve farmlands, as the following comment suggests:

I think we are coming back to the land [and getting to know where things are coming from]. I also think people are a lot more aware, especially in this area, that farmland is being eaten up, and that without farmland they're not going to be able to have all of the fresh fruits and vegetables they want and are used to getting. Another thing... is all of the food borne illness scares that have been happening. People are trying to figure out these chains of events and saying...maybe factory farms are not the safest ways to get our food, or shipping things across the country might be hazardous. People are looking into [farmers] markets, 
CSAs, and growing their own food and realizing all of the other benefits that come from it such as they enjoy farming, or are saving money on gas, less packaging, or it tastes better. Then they get to know their farmer and it creates this whole community....They go to the market for one reason and then they get all of these other things come with it (M4).

The comment first suggests that managers perceive consumer attendance at the markets as a result of a desire to reconnect with the land. However, going "back to the land" is not accomplished by farming or gardening rather it is through the experience of getting "to know" one's farmer. Through getting "to know" one's farmer, the markets become the site where consumer choice buys (or protects) a little piece of the agricultural landscape from an expanding urban metropolis. Ultimately, however, the farmers markets and CSAs are selling an experience that is playing off of green consumption practices. Green consumption refers to the socially and environmentally conscious purchases that are perceived to solve problems related to the health of the environment or the health of one's family or community. Green consumption can also be defined as a lifestyle as one manager notes:

You might as well get a product you feel good about. It's a really good, feel good, experience for everyone. People feel that they may be closer to a sustainable lifestyle. In small ways you buy recyclable products at home, go to the farmers markets...it's getting our lifestyle back with the greater good and giving our children a future (M3).

\section{Food Scares}

Another reason expressed by managers for the rise in popularity of farmers markets and CSAs is the threat presented by food scares. Food scares, in the 
opinion of the managers, instilled a suspicion of the conventional food provisioning system in the average consumer. People have become aware of the concentrated animal feedlot operations (CAFO) and are concerned about the lack of corporate accountability in the food system. The consumer is more informed about the link between purchasing a product raised in CAFO and its possible effect on the health of the consumer and the environment. The manager's following comment illustrates this point:

I think people have a distrust for the large factory farms and the large containment facilities for raising animals in agriculture...I think it's a safety issue. When there was the big spinach scare people came to the market and people bought spinach and were comfortable with it. They feel there's accountability (M3).

\section{Food Miles}

The next issue that managers considered to be addressed by consumers' green consumption practices is a reduction in food miles. The concern over reducing food miles plays off of two concerns: peak oil and supporting the local economy. In theory, by linking purchases with a local producer they are both reducing their environmental impact by reducing the amount of oil needed to transport food by decreasing the distance food travels to market, but are also keeping the dollars in the local economy. The managers usually tie the two concerns together:

It just means supporting the local economy...just a little bit of the local economy. Food doesn't have to travel as far either...I have learned about the impacts of the food that travels from other countries, [so] I try and buy local (M2). 
In recent studies, food miles as a measure of the sustainability of the local food system, have been challenged. For instance, David Coley et al. found that the concept as currently used has little value and that it is the carbon emission per unit of produce over the transport chain that really matters $(2009,154)$. Purchasing local food, they argue, does not always translate to a lower carbon footprint. Through their comparison of two food distribution systems, their findings show that carbon emissions from many customers traveling to local farm shops can be greater than the system of cold storage, packing, transport to a regional hub, and final transport to a customer's doorstep by a large-scale vegetable box supplier. A similar 2005 report by the United Kingdom's Department of Environment and Rural Affairs (DEFRA) found that $48 \%$ of food miles were generated by customer shopping trips. The studies are part of a bigger trend challenging the notion of food miles as a sustainability indicator and the need to better understand and confront the global food commodity network. However, farmers market managers and the general public still view food miles as a measure of the food 'sustainability.'

\section{Preservation of Farmer Livelihoods and Farmlands}

The other concern is how an interest in the preservation of farmer

livelihoods and farmlands is acted out at the markets. Local politics and the construction of an urban growth boundary inform most of the managers' narratives on this issue. At times they put an emphasis on the land's best use, whether that be in agriculture or not, and issues of sustainability. The main points, however, are on creating niche markets that allow farmers or producers to get a higher return on 
their product by selling directly to the consumer. These strategies are often advocated by farm preservation advocates and county extension agents as methods to boost farmer revenues. Those strategies combined with the construction of an urban growth boundary allows for the close-in nature of many small-scale farms and allows the consumer to see a direct link between their purchase and the preservation of the small-scale farmer. Ultimately, however, the managers stress how the preservation of the small-scale farmer depends on urban demand and consumer choices,

People with money living in urban areas, if their demand increases for what these farmers have, they are going to preserve [farmland]. If [farmers] can't make a living...then they are forced to sell their land, but farmers want to farm...I'm excited that in Oregon people are aware of this (M4).

I think demand for local foods means that farmland is valuable as farmland and lands should be put to a certain extent the highest and best use. Until now, when compared to building a bunch of homes or a community center or shopping center, farmland couldn't compete. I think if you're creating a niche market for local foods then perhaps that raises the value of farmland in a way that a market could capture the value of that...so yes, I think the market will preserve that land as farmland as it becomes, price wise, valuable to have in the mix (M1).

They keep the small farms alive. There are two ways a farmer can survive. They can survive by wholesaling or they can retail. If you wholesale you get about half the money you get at retail...If you're a small farmer you really need to have retail outlets...to have farmers markets or CSA....allows small farms to get...much needed retail [prices] coming in. Without the retail market a lot of these little farms would not be able to survive. In fact, a lot of them grow exclusively for farmers markets. Also, because a lot of our farmland is so close in, it is very doable to go out to say West Union Gardens and just get berries directly from them. All of those sources I think are very important in keeping those small farms going (M3). 
The result of the consumers' green consumption practices is a community built on a multitude of decisions to purchase local and attend farmers markets whether it be health, the environment, or supporting the small scale farmer. The community is placed in contrast to the "prepackaged and sterile experience" (M3) of conventional grocery stores; rather it's described as a more authentic experience, "a very friendly place" (M3) or "a place to get to know your farmer" (M4). It's the process of getting to "know your farmer" where the community is built and the social networks are formed that bring the customer back. The relationship links the consumer to the producer and it's a relationship that, "carries overtones that somebody is laboring in the fields. They're working to bring us food, and there's a sense of stewardship for the land" (M3).

A desire to better understand the social and environmental impact of one's consumer choices can have a positive impact. The consumer who better understands the links between their consumer patterns and the health of the planet is a more informed consumer. However, a need to better understand the difficulties and challenges of the small-scale farmer is needed to move beyond common environmentalist arguments revolving around green consumption. They can erase the questions about who gets to participate at the markets and who has access.

Education can offer the first step to move beyond common environmentalist assumptions about local food. Being locally grown does not always mean the food is grown more sustainably or is even fresher. Local organizations such as Slow Food Portland and Ecotrust's Food and Farms programs help inform people about 
the seasonality of food production and what foods are available locally and at specific times of the year. One manager notes that before she became involved as the market manager she really did not know what was available from season to season or grown locally. Education programs can be the first step to help bridge that disconnect and provide more insight into local food.

The difficulties faced by farmers are another overlooked part of the local food system. Farmers face a number of difficulties such as meeting food safety or organic certifications, threats from developers, and facing the problems any small business might face, such as the diversity of expertise that they may need to get off the ground:

The family farmer or small-scale farmers have to find their niche and they're not all marketing majors or marketing strategists. They may have an excellent way of growing food but they don't know how to turn that into an enterprise (M1).

According to one manager the success of marketing depends on what she calls the three p's--presentation, personality, and product--to describe the most successful farmers at the farmers market. It's not enough for the farmer to grow a good product but it is also important to foster the social networks that keep the customer coming back such as remembering names and making the stand attractive. The farmers are in some ways selling a brand, and whoever's brand can give the consumer the better experience, one that may give them a connection to the land, albeit indirectly, will be more successful.

The third step towards better understanding local food networks is how to make the markets more inclusive. Farmers markets are sometimes noted as "white 
spaces" and providing food that caters to "yuppies" and the upper classes. The managers note that until recently that was largely the case in Oregon, but with farmers markets now accepting food stamps the markets are getting more families who are on food stamps and the Women, Infants, and Children (WIC) program. The Forest Grove Market is also unique in that it serves as a venue for the nonprofit Adelante Mujeres' sustainable farming program. Adelante Mujeres' mission is the holistic education and empowerment of low-income Latina women and their families. The organization runs a number of programs, one of which is the organic farming program and the farmers market that is part of the microenterprise program. Adelante Mujeres has a farm and they offer land to Latino farmers who want to participate. First, they have to participate in a 22 week course, 11 weeks devoted to small business development and 11 weeks to farming. The farming has a focus on organic techniques. Finally, after completion, Adelante Mujeres helps the participants get access to land, build their plots, provide ideas about what to grow, and offer basic English skills for participants to interact with the customers. During the training program Adelante Mujeres provides a free spot at the market. While other initiatives support immigrant farm worker entrepreneurs (i.e. MicroMercantes in the Portland area), Adelante Mujeres is unique in being a farmers market devoted to this effort. 
Consumer Survey

Between September 19, 2009 and October 3, 2009, I collected 79 consumer surveys $^{2}$ at three farmers markets in Washington County. Of the completed surveys $40 \%$ came from the Forest Grove Farmers Market, 57\% came from the Hillsboro Farmers Market, and 3\% came from the Beaverton Farmers Market. Thirty-three of the respondents identified themselves as male, 30 identified themselves as female, and 16 did not list a gender.

Those who chose to participate in the survey cite a variety of reasons for their decisions to shop at a local farmers market. The preservation of farm life, sustainability, and supporting the local economy are central themes informing people's decisions to purchase local. In this section I explore consumer motivations and cases that illustrate reasons to purchase local food from farmers markets.

Oregon's history often evokes images of a region that is the "land of milk and honey" and the "Eden at the end of the trail" (Robbins 2004, Works and Harvey 2005). Romanticized conceptions of Oregon's agricultural landscapes are played out today in individual decisions to shop at farmers markets. Survey respondents view Oregon's agricultural landscape as an "important part of the history and status of the state" (C15-FG). $94 \%$ of the survey respondents identify Oregon's agricultural landscape as an important component to Oregon's cultural

\footnotetext{
${ }^{2}$ Surveys were coded by giving each consumer a number then identifying the location where the survey was taken, BV standing for Beaverton, HB for Hillsboro, and FG for Forest Grove. Example: C1-BV would mean it was the first survey taken and it took place in Beaverton.
} 
identity, while $97 \%$ of the respondents see small scale and family farms as a vital component to Oregon's landscape. It is those pastoral images that inform many people to purchase local because, after all, it is Oregon's farmland and farmers that, "makes the state what it is" (C5-FG).

Attending farmers markets thus becomes the venue for people to support their local economy and help protect the landscapes they care about through their consumption practices. Comments like "[farmland] adds to beauty and economy" (C30-FG) highlight the relationship between preserving farm life for the beauty it adds to Oregon's landscape but also for its important role in the local economy. When asked to rank the importance of decisions to purchase local, $61 \%$ rated the preservation of farm life and supporting small-scale farmers as the most important. In a similar set of questions $57 \%$ ranked their decision to buy local as a means to support the local economy.

However, when the survey respondents were asked to define local the results were mixed. In some cases the food was local by virtue of it being sold where the customer was. In other words it was local because it was there in front of the customer. However a plurality, 38\%, defined local food as food produced in the county, $24 \%$ defined local food as food coming from the state, $19 \%$ said it was the Pacific Northwest, 16\% less than 100 miles, and 3\% described local as something else. The results are similar to other studies that show the county to be scale at which the largest percentage of consumers define local (Selfa and Qazi 2005). A survey of consumers at 15 Canadian farmers markets showed the 
majority of patrons to recognize food as coming from the region as local (Smithers, Lamarche, and Joseph 2008). The results indicate the varied meanings and understandings of the ways of local food is socially constructed and defined at the farmers market.

Urbanization presents new opportunities for farmers to sell directly through venues such as CSAs and farmers markets, but it also presents challenges such as increased rents and restricted access to land. There seems to be a general understanding among consumers that the small-scale family farm who could sell directly through these markets is disappearing largely as a result of urbanization-"being encroached upon" (C10-FG), "going away fast" (C11-FG), "dwindling" (C29-FG), "too little, too late" (C38-HB), "fewer farms more urban sprawl” (C46HB), "family farms are going away" (C76-HB), "small farmers are struggling with high property values" (C73-HB) are but a few comments gathered from consumers about farmland in Washington County. Not surprisingly then, 95\% percent of the survey respondents believe farmland should be protected from urban growth.

The results of the survey also show an interesting trend between consumption habits and beliefs. Fifty-six percent of the respondents purchased less than $10 \%$ of their food from farmers markets or CSAs, yet most farms are working at capacity to meet demand. With $75 \%$ of the respondents attending farmers markets on a weekly basis, the results show that consistent attendance and a relatively small percentage of one's food purchases geared towards local food can help make local food systems more socially and economically viable. 
Another striking result of the survey was that $89 \%$ of the respondents believed that their food purchases at the farmers market could help preserve small scale farms, but less than $10 \%$ of food purchases come from farmers markets. All farmers interviewed for the study were at capacity and many were looking to expand. The demand is clearly there and no studies have been conducted to date analyzing Oregon's ability to supply local food year round to the region. Nine percent remained neutral on the issue of their purchases protecting small-scale farms and only $2 \%$ did not see their weekly food purchases as a means to help preserve small scale farms. Ninety-four percent of respondents indicated that they would like to see more venues offered for direct sales. This strategy would make it more plausible to meet both consumer demand and provide the extra outlets needed to allow small-scale producers to expand. Perhaps, making local food more accessible year round with more outlets available for both consumers and farms could play a significant role in preserving agricultural lands and livelihoods, albeit a small percentage.

Consumer interest in buying local is nonetheless tied to the idea of "buying into" a green lifestyle, one where the ideas of sustainability, farm preservation, and the environment motivate food purchases.

Oregon farmers grow healthy food and try to keep a sustainable environment. We don't want our land turned into tract housing. Oregon is traditionally a green and healthy state. We love our fresh produce and lovely fields of wheat and clover. We are proud to contribute to improving the health and lifestyles of not only local people but other states as well. Keep Oregon Green (C44-HB). 
The comments suggest that Oregon farmers are "green" and preserving them maintains Oregon's status as a "green" state and a "green" state is equated with being a healthy state. The purchases become a means not only for the customer to link oneself with the labor of the farmer but also a means of buying a landscape that they believe is more sustainable.

In contrast to the market manager's understanding for the reasons people attend farmers markets, issues such as 'food miles' and the face-to-face relationships rarely came up. In one set of questions about ranking reasons for attending a farmers market, reducing food miles and face-to-face relationships were by far the least important in decisions to purchase local. Similarly, in another set of questions only $3 \%$ of respondents ranked environmental impacts as the most important, although it was the highest second and third ranked choice for deciding to purchase local. Food safety was also reported lower than protecting farmland from urbanization and supporting the local economy. Decisions to shop at farmers markets were most often based on supporting the local economy, and the smallscale farmer is very much a part of that. 
CHAPTER 4

\section{NARRATIVES OF FARM LIFE: THE FAMILY FARM AND “LIFESTYLERS” IN WASHINGTON COUNTY}

The narratives of farmers participating in local food networks offer insight into a number of issues that affect daily life on farms. In this chapter I explore the narratives of farmers to suggest that two main types of farmers participate in local food networks: long standing family farmers and more recent farmers who began farming later in life as a lifestyle choice or hobby. I do not argue that all farmers participating in local food networks have similar experiences or experience farm life equally. Rather my intention is to reveal the complexity and diversity of issues facing farmers selling locally through farmers markets or CSAs and introduce broader themes.

The first set of farmers are family farmers who converted to selling locally through CSAs and farmers markets due to changes in the local economy, financial reasons, or out of necessity. Selling locally for these farmers has helped preserve their way of life and brings more joy into their work through face-to-face relationships with their customers. The farmers do not prioritize environmental ideals as primary motivations for farming, but do view their activities as benefitting the greater environment and community. The farmers place their operation and lifestyle in contrast to city life and tend not to idealize rural life. Rather they view their operations as productive land uses and it's their productivity that helps contribute to Oregon and Washington County's sense of place. The agricultural 
landscape is viewed clearly as a space of production not as a space for leisure or consumption among the family farmers.

In contrast, the second type of farmer is the lifestyle or hobby farmer who learned to farm on the job and moved to the countryside with specific aspirations and idealized images of the countryside. The spaces occupied by these newer farmers are spaces of both production and leisure. The lifestyle farmers increasingly view the agricultural landscape as a cultural landscape valued for its consumption purposes and as a place more "natural" than the city. One farmer notes, "I wanted my kids to grow up with space to run and play and to see nature and live in nature (F6)." Moving to the countryside became the escape from the city for many of the recent farmers who had lived in cities most of their lives. Once out in the country the new farmers engaged in a number of place making activities and filled new social roles becoming active in local food politics, farmland preservation issues, and providing more intern and work opportunities for younger people interested in farming.

Despite apparent differences, many commonalities exist between the two types of farmers I describe. Farmers are concerned about the role they get in the planning issues that affect their livelihoods and do not think the rural voice always receives fair input in the planning processes. However, urban growth is generally viewed as an enabling process for them to become more viable as long as they are protected from the urban growth. Selling directly to a large purveyor is also preferred in most instances. In addition, the farmers interviewed all seek to be 
"sustainable" and support the environment surrounding their farms. Finally, the farmers also face the problems all farmers face such as dealing with the weather, and managing time, labor, and money.

Table 1. Profile of Farmers*

\begin{tabular}{|c|c|c|c|c|c|c|c|}
\hline $\begin{array}{l}\text { I.D. } \\
\#\end{array}$ & Name & $\begin{array}{l}\begin{array}{l}\text { Size } \\
\text { (Acres) }\end{array}\end{array}$ & $\begin{array}{l}\text { Year } \\
\text { Began } \\
\text { Farming }\end{array}$ & Types of Crops & $\begin{array}{l}\text { \% income } \\
\text { from } \\
\text { Farming }\end{array}$ & $\begin{array}{l}\text { Sells } \\
\text { at } \\
\text { CSA }\end{array}$ & $\begin{array}{l}\text { Sells at } \\
\text { Farmers } \\
\text { Markets }\end{array}$ \\
\hline F1 & $\begin{array}{l}\text { Karen and } \\
\text { John } \\
\text { Bradley }\end{array}$ & 80 & 1978 & Mixed Berries & $70 \%$ & & $\mathrm{X}$ \\
\hline F2 & $\begin{array}{l}\text { Vicki } \\
\text { Huntley }\end{array}$ & 50 & $1940^{1}$ & $\begin{array}{l}\text { Mixed } \\
\text { Vegetables, } \\
\text { Fruit }\end{array}$ & $100 \%$ & $\bar{X}$ & $\bar{X}$ \\
\hline F3 & $\begin{array}{l}\text { Andrew } \\
\text { and Cari } \\
\text { Johnson }\end{array}$ & 5 & 2002 & $\begin{array}{l}\text { Fruit, Mixed } \\
\text { Berries, Mixed } \\
\text { Vegetable }\end{array}$ & $5 \%$ & $\bar{X}$ & \\
\hline F4 & $\begin{array}{l}\text { Leora } \\
\text { Davis }\end{array}$ & 2.2 & 2000 & $\begin{array}{l}\text { Mixed } \\
\text { Vegetables, } \\
\text { Fruit, Eggs, } \\
\text { Goat Cheese }\end{array}$ & $25 \%$ & $\mathrm{X}$ & \\
\hline F5 & $\begin{array}{l}\text { Carol } \\
\text { Simpson }\end{array}$ & 1.5 & 2008 & $\begin{array}{l}\text { Mixed } \\
\text { Vegetables, } \\
\text { Fruit, Grapes, } \\
\text { Wine }\end{array}$ & $2 \%$ & $\mathrm{X}$ & \\
\hline F6 & $\begin{array}{l}\text { Stacy } \\
\text { Jacobsen }\end{array}$ & 9 & 1999 & $\begin{array}{l}\text { Mixed, } \\
\text { Vegetables, } \\
\text { Fruit, Herbs }\end{array}$ & $50 \%$ & & $\mathrm{X}$ \\
\hline F7 & $\begin{array}{l}\text { Tracie } \\
\text { Howard }\end{array}$ & 6 & 2005 & $\begin{array}{l}\text { Mixed } \\
\text { Vegetables, } \\
\text { Fruit }\end{array}$ & $100 \%^{2}$ & $\bar{X}$ & $\bar{X}$ \\
\hline
\end{tabular}

*All names are pseudonyms.

1Year her family bought farm. She is a second-generation farmer.

${ }^{2}$ Farmer is currently working at a loss.

\section{Family Farmers}

John Bradley's family has been growing berries since 1948. He and his wife began farming in 1978 and bought the 80 acres they farm in 1984 . John grew up two miles from where he currently farms and has lived in the area all of his life. When he and his wife began farming their entire harvest was going to canneries to 
be processed and shipped abroad. They were unsatisfied with the consistently low prices they were getting at the canneries and looked into the farmers markets. Shortly, they realized that at the farmers market they could get more than a dollar more a pound for their product. They added more markets and began planting berry varieties geared towards farmers markets instead of the canneries.

Selling locally has brought a greater return on their labor and product but the two rarely say that it is the extra money that they enjoy most about participating in a local food network. They value the recognition and interaction with the customer the most, which is something they claim did not happen when they sold their product to the cannery to be shipped abroad and used in Haagen Dazs Ice Cream. The interaction and customer appreciation makes farming for them a happier situation.

Selling locally, however, is not without its challenges for John and Karen. They are seeking to expand their operation and already sell at 17 farmers markets in the Portland area through the course of a week. Finding enough people to work their markets is a continuous struggle:

We are at markets just about any given day. Tuesday, Wednesday, Thursday, Saturday, and Sunday we have two, three, or four markets happening. The challenge is finding somebody to work. We are doing so many markets it's not always me or my kids working....It's my kids' friends, nieces, nephews, and friends who aren't as invested or do not know all of the details about what we do. If someone asks them a tough question about our farming practices they just say we're sustainable and that's the extent of it. They don't always know how long we have been doing this and other things. We train them and we give them a couple sheets of information, but they don't always remember it. 
Travel costs can also erode away the extra income provided by selling niche products locally. Traveling to 17 farmers markets throughout the region generates a significant amount of costs for distributing their product. The product does not always sell-out at the farmers markets either and the remainder is sold to processers. Although farmers markets account for $60 \%$ of their sales the remainder goes to the canneries. This is less ideal for them because they do not get as high of a return on their product, but by selling through both venues they are able to remain a viable and successful farm operation.

Vicki Huntley produces vegetables and fruits, and local is important to her because as of four years ago everything grown on her farm is sold directly to the customer. She is proud that $100 \%$ of her income is from local customers. Before selling locally her farm was a dairy farm and all their milk and grain products were shipped out of the state or abroad. The returns they got for their product came at a much later time and often did not cover the costs to produce their products. Vicki and her family were faced with the choice of selling the farm that had been in the family since the 1940 s or find another way to make a living on their land. They had already been selling their surplus vegetables from the family garden at the Hillsboro Farmers Market and saw that as a possibility to make their farm profitable. Vicki says, "selling locally, well, it saved this family farm." Now, Vicki and her 50 acre family farm support four other families who work on the 
farm, provide food for 810 families in the CSA, and sell at five farmers markets in the Portland metropolitan area.

Selling locally provides a stable financial picture for Vicki's family. The CSA model provides cash payment upfront to cover the costs of production and selling at the markets provides cash payment within 24 hours from when the picking was done. In addition, Vicki points out that they are usually thanked and shown gratitude after the sale. The overall situation, Vicki claims, is better for her family both financially and emotionally, leading to increased happiness in her family.

Vicki and her family are also devoted to preserving farmland and adhering to the ideals of sustainable agriculture. Her farm uses ecologically sound management practices such as composting and using cover crops, but also provides habitat for beneficial wildlife. Her operation adheres to Altieri's (1995) principles of sustainable agriculture, but she is not certified organic:

We are not certified organic. We don't pay a third party to tell us how to farm. I think we are actually cleaner...I don't know if I can say we are cleaner than organic but we don't use anything [chemicals, pesticides, or herbicides]. We fertilize with compost and we use cover crops to put good stuff back into the soil...I guess you could call us sustainable. I can't use the " $O$ " word because I don't pay to use it, but that's where we're at.

The comment also points out the difficulties and time constraints of becoming a certified organic farmer. Farmers often do not want to pay the extra price of becoming certified organic, nor do they always have the time or knowledge to fill out the required paperwork and maintain the certifications. Thus, the 
certifications can act as a barrier to entry for many farmers who would like to be certified organic and capture some of the price premium organics demand but cannot cover the organizational costs (e.g. Guthman 1998; Mutersbaugh 2002). Rather the farmers who do not, or cannot, become certified organic label themselves as "sustainable," depend upon their local reputations, or offer a visit to their farm if consumers are concerned about the product.

Work-hours at the production level are also a challenge to selling locally. Vicki says that harvesting vegetables and presenting them for sale takes much more time than milking cows and harvesting wheat. They overcome those challenges by engineering their own farm equipment to fit the scale of their farm to reduce the amount of time it takes to harvest. The most recent machine they built was a harvester that will wash and box their produce. She hopes the new harvesting machine will work and be able to cut harvesting time in half.

\section{Lifestyle and Hobby Farmers}

Andrew and Cari have been farming 5 acres since 2002. They grow berries, pears, apples, and a variety of vegetables. They do not perform all of the farming themselves. Rather they farm part-time and hire a full-time farm manager and three farm hands to help them with the work on the farm. All of their produce is sold through their CSA and to Bon Appétit, a large catering company that provides food services to corporations, colleges, and universities. They are satisfied with their current growing and marketing system, but the husband also works from home as a 
software engineer and web-site developer and it is unclear how well they would make ends meet if not for his job.

They are committed to growing produce "sustainably" and giving urban dwellers the opportunity to experience farm life and understand where their food comes from, "within shouting distance of where they live." They see the urban growth boundary as a means to provide a connection between urban residents and rural farmers, but are very concerned about the economic impact urban and rural reserves designations and urban growth onto prime farmlands can have on the local economy:

Farmland needs to be around for the long term. Agriculture is a very stable economic activity and a lot of the lands people are proposing to take into the urban growth boundary, especially, for industrial uses are based business cycles that are at the whims of what other countries do....All the high tech jobs and all the manufacturing jobs are being exported, but agriculture is stable.

Andrew reveals a difficulty experienced by many of the farmers participating in local food networks. Their success is based on being located in close proximity to urban centers but as urban growth encroaches onto farmland, or as the urban growth boundary is expanded to include formerly productive farmlands, their time is often spent trying to keep urban growth at bay. Andrew is active in a number of organizations to fight urban growth and preserve farmlands and is very concerned that farmers often do not get an equal say in the land use politics that shape their livelihoods:

A large tract of flat land with some of the highest grades of soil in the world is still slotted for industrial use....It [the soil] is the best of the best and the county wants to cover it with asphalt. 
What the developers and planners forget is that agriculture is Oregon's second largest industry. Why are we going to sacrifice the second largest for the first largest, when the first largest is dying? I tell you because there are a lot of developers lobbying these guys day after day. Also, all of this happened during the busiest time of the year for the farmers. I mean how easy is it in July and August for farmers to get off their tractors to make a meeting at 1:00 in the afternoon? It silences their opinion...current designation does not serve rural interests.

The comment is one echoed by many of the farmers and it highlights the tensions between urban and rural interests. Urban interests seek more development and growth while farmers see a stable economic activity and food and culture at stake.

Leora Davis and her husband grow a variety of vegetables, some fruit, and eggs on 2.2 acres. They state that a strong desire to give back to the community and promote good health through good food was the motivation to become farmers. Leora's husband grew up on a farm in Central America, but Leora had no farming experience, other than a garden in college. However, they point out that farming in Central America is much different than farming in Oregon and garden experience does not equate to farm experience. Their farming experience developed largely through trial and error. They get about one-quarter of their income through farm sales. Leora works full-time as a family physician and her husband works the farm full-time. They do not depend on interns or any other laborers and are operating at full capacity:

It's a 24 hour a day job....We never go away with our family and we have three young kids. That's definitely a sacrifice for us. We work around it and go away occasionally. We take a week 
off and my sister does the harvest. Farming can consume all of my extra time from when I wake up at 4:00 a.m., put in 2-3 hours on the farm, and head off to my other work by 7:30. I come home from work at 6:00 p.m. and put in another 3 hours in the summer time. My husband works it full time while taking care of the kids. It's a lot of work. Then there are the pests. Being an organic [not certified] farmer is hard.

Carol Simpson, amongst all of the farmers, is most clearly a hobby farmer. She began farming in 2008 because "all of the CSAs that were near my house were full when I looked into subscribing to one." She considers herself an entrepreneur rather than a farmer. Farming is something that she does on the side as a lifestyle choice. She also works as a property manager, in sales, and as a web site designer. With her wide range of professional skills she does not see it practical to devote herself full-time to farming. The fact that her family owns a vineyard where she has a 1.5 acre space to farm and the incomes from her husband and her other jobs is the only way she believes she would be able to farm. She believes less than $2 \%$ of her entire income is generated through farm sales.

Starting the CSA for Carol was not about generating significant economic returns on her labor. Rather she favors farming more as a form of leisure and recreation. Farming as a hobby while maintaining her other jobs provides her with a stable economic situation and the opportunity to expand upon her initial interests in gardening. Carol describes her activities as a great way for her to "care for the environment" and provide food for her friends and a growing community of people interested in eating locally. The growing interest in local food and the popularity of working in a local food movement is something that Carol says is more exciting 
than her other jobs even though it is only a small part of her income and what she does.

Stacy Jacobsen is a certified organic farmer who learned to farm on the job. She and her husband began farming in 1999 and grow mixed vegetables, fruit, and herbs on nine acres. She is active in supporting other farmers through teaching and sponsoring workshops and hosting local garden clubs. She hires five full-time employees and a part-time employee at the height of the season. She has room for four people to live on the farm and provides health insurance for her employees that work more than 100 hours a month. She hopes that by providing farming opportunities for young people she can help keep farm land in use by creating an interest in farming for the next generation:

I think the biggest threat to land staying in farm use is the fact that farm use does not pay the price of the land. Coupled with this is that most farmers' average age is about my age, which is old. As farmers get to the point where they want to retire or just can't do it anymore and want to sell, [farmland will be gone], unless [the farmer has] family who wants to get into farming.

The changing demographics of farmers are a concern shared among many of the farmers. According to the 2007 United States Department of Agriculture (USDA) Census the average age of a farmer increased from 55.3 in 2002 to 57.1 in 2007, while the number of farmers 75 years and older grew by 20 percent from 2002 and the number of farmers under 25 years of age decreased 30 percent (USDA NASS 2007). The farmers acknowledge this trend and are worried about the next generation of farmers. Stacy, similar to many of the other "lifestyle" 
farmers, hopes the work opportunities she provides young people can create a new generation of farmers.

Tracie Howard began farming in 2005 after having a career in public health. She quit her job and went back to school where she learned about sustainable agriculture and was introduced to the CSA model. Prior to her classes her only farm experience had been growing food for her family in the backyard garden for the past 20 years. Her farm is currently working at loss, but she describes this difficulty as typical of any small business starting out. She is looking to expand her operation and begin selling a more diverse range of products.

Farming, Tracie claims, fulfills her emotional need to be a part of a community and though she farms within the urban growth boundary she is optimistic about the future of her farm. With more development coming up around her farm she hopes that one day she can be part of the fabric of the local community by developing relationships with the neighbors:

There are 120 houses going up across the street. That means it is important for me to develop a relationship with those neighbors, so that if they do have issues or concerns they come talk to me about them. I want this farm to be the community farm. My goal is to only sell my produce on this farm through CSA pickup and the farm stand so people in this neighborhood can pick their child up at school, walk to the farm, purchase their vegetables, and then walk home. How much more local can you get? I want to be seen as part of the fabric of the community (F2).

Tracie describes her new social role in the community as the person who can help reconnect people to the land. She explains that many people are not able 
to move to the country and start their own farm or have the necessary means to reconnect themselves with the land, but her farm offers that opportunity to people in her community. 


\section{CHAPTER 5}

\section{LAND-USE AND AMENITY PRODUCTION: THE ROLE OF CAPITAL AND AUTHENTICITY IN SUSTAINING LOCAL FOOD NETWORKS}

Farmers who become active in local food networks engage in a number of place-making activities and fill new social roles. The farmers' new social roles include the production of culture, landscape, and food. This chapter is based on farmer discussions about their motivations to become farmers, land-use ideologies, and amenity production. From the discussions, the role of economic and social capital became a key theme explaining farmers' motivations and capacity to begin participating in local food networks and their success. Authenticity also became a key theme for explaining on site farm activities and motivations.

In the first section I argue that access to both economic and social capital is important for the success of farmers participating in local food networks.

Economic capital is the most material form of capital and is needed to cover basic needs and the upfront costs of farming such as farm equipment and access to land. Social capital, popularized by Robert Putnam's (1993) work on democracy and civic traditions in Italy, refers to the support that comes from being part of a larger group or community. This type of capital opens up opportunities for farmers to begin production by minimizing their risks, but also creates an invested group of individuals willing to become active in local farmland preservation issues and advocates of sustainable agriculture. 
In the second section, I explore farmer production and amenity activities and land-use ideologies. In so doing I argue that the idea of authenticity plays a significant role in creating the countryside and informing both farmer and consumer activities on the farm. This is most apparent with the "lifestyle" farmers described in the previous chapter, and have access to more economic and social capital to construct an "authentic" farm experience. However, all of the farmers interviewed for this project combined some amenity and productive land-uses and attributed their farm activities as adding to Washington County's sense of place.

However, for something to be defined as "authentic" something has to be "inauthentic." For Relph, inauthenticity is "an attitude which is closed to the world and man's possibilities," but it is also "stereotypical, artificial, dishonest, planned by others, rather than being direct and reflecting a genuine belief system encompassing all aspects of existence" $(1976,80)$. "Inauthentic" then comes to represent the standardization of the industrial food provisioning system, unsustainable processes, and the resulting uniformity of the landscapes those systems create. In contrast, authenticity for Relph is "a genuine experience of the entire complex of the identity of places," but also a "belonging to your place both as an individual and as a member of a community" (1976, 64-65). Thus, "authentic" farmer activities and the landscapes they create are placed in contrast to industrial and commercial food provisioning systems and the perceived low quality of food provided through those outlets. Discussions about "authentic" farmer land- 
uses and on-site activities stress the social connectedness and experience their farm sites inspire and offer over the industrialized food system.

Thus, authenticity becomes a key explanation for discussing farmers' motivations to become involved in local food networks and how they perceive themselves as contributing to the character and sense of place of the region. In addition, using authenticity as a point of analysis helps explain farmers' productive and amenity land-uses and how the agricultural landscape is changing from a landscape of production to a landscape of consumption.

\section{The Role of Economic and Social Capital}

Capital is vital in creating the opportunities for farmers participating in local food networks and sustaining their operation by making them economically viable. Two important types of capital come to mind in creating successful farms participating in local food networks. The first is economic capital and that includes the capital needed to cover basic needs, farm expenses, and the cost of the land. The second form of capital important in the creation and sustainability of local food networks is social capital. Social capital is the support farmers garner from their customers but also the support given to farmers from their pre-existing social networks. 
Economic Capital

Farmers depend on two types of economic capital to be successful. The first is for their farming activities to generate enough income to cover basic needs such as food and other personal expenses. As discussed in the previous chapter, this is a constant difficulty faced by many of the farmers. Without a second income many of the farmers would not be able to make a living season to season, but it also shows the class-based nature of many of the new farmers participating in local food networks. Many of the farmers had past professional careers, retain current jobs in health care or in the technology industry, or depend on the career of a spouse to ensure financial stability. Carol Simpson notes that, "I'm fortunate because I'm married and we have two incomes and I don't think I would be able to start this farm if I didn't have a second income." The second income provides the extra capital for the farms to get started and protect themselves against the risks of farming, such as crop failure.

The second type of economic capital vital to farmer success is the capital needed to cover the cost of the land and other farm necessities such as machinery:

You have to have enough capital up front when you start [farming] to cover for the fact...that your new farm or business will operate at a loss for the first three years. You have to have enough capital set aside to live off of for your own personal expenses, plus the capital that it takes to start the farm. The equipment for farming and for starting up a farm is expensive. You can't get a workable used tractor for less than $\$ 10,000$. That's a lot of money to have to start out with (F7).

Loan programs exist for beginning farmers, but as Tracie Howard notes, many of these loans require a minimum of three years farm experience to qualify. In 
addition, the USDA beginning farmers or ranchers loans require the applicant to put down a minimum of $5 \%$ of the purchase price of the land (USDA: FSA). She is worried that those requirements work against young farmers who would have physical capabilities to withstand farm work and the most time to pay off the loans and become successful but do not necessarily have the upfront capital to put down on purchasing land. She worries that despite programs to help beginning farmers it is not enough.

\section{Social Capital}

The less obvious form of capital allowing for the success of farmers participating in local food networks is their social capital. Social capital can be used as a geographic concept to refer to how "the interactions between individuals [and]...the quality of relationships between individuals is shaped by, and itself shapes the character of, the contexts in which they live in" (Mohan and Mohan 2002, 193). This is especially true of the lifestyle or hobby farmers mentioned in the previous chapter. Local food networks depend on a wide variety of supporters from local governments to the media, but perhaps the most important support comes from the pre-existing social networks with an often highly educated and affluent group of friends willing to support these farms. As one farmer notes, "Every small farmer I have met has a college degree...the vast majority of us have advanced degrees and several have PhDs" (F7). The fact that farmers, in particular the lifestyle farmers, are already in a highly educated and often affluent social 
network provides the context for their friends to serve as the initial support needed to begin farming and become successful. "A lot of the people that became members of my CSA are my friends. They all have the same passions about local food...A lot of them are friends and that's because we started small" (F5). It is the farmers' social capital rather than a history as an established farmer that provides the initial success for farmers looking to participate in a local food network.

Farmers also depend on the actions of individuals to provide additional support such as reducing the rents on the land and providing the space to farm. Tracie Howard farms six rented acres on a parcel of land zoned for twenty units per acre. Her farm is four blocks from a bus stop and four miles from a max line. Her position close to public transit and within the UGB has driven up the value of the land to where the value of the development rights far exceeds that of farmland. However, the land is not on the market and, "[The landlord] wants to keep the land in agriculture, and she works with farmers, [and] leases the land to me for less than fair market value in order to help support me" (F7). Tracie is not the first farmer to rent the land from this landlord for less than fair market value. She explains how she is following in the path of other farmers who farmed the same plot and moved on to bigger operations.

The farmers pre-existing social networks also provide the social capital needed to help market their farms. Farmers are struggling to keep up with demand; they have long waiting lists, and are working at full capacity. Marketing and 
getting customers is made easy by their professional skills and networking abilities but also through their social and familial ties:

We sell to Bon Appétit campuses, Intel, and the Yahoo! Campus. That's pretty lucrative because they pay a fair value amount for the produce they buy. They are committed to farmers like us and very supportive... and the connection to Bon Appétit came through Steve's [the farm manager] father-in-law. A lot of the other subscribers are friends and family. It's all become word of mouth. We CSA farmers don't have to advertise $(\mathrm{F} 3)$.

CSA members and customers also become active in supporting farmland preservation and become advocates of sustainable agriculture. One farmer notes, "Many of our subscribers who become active [in the CSA] then become vocal. Subscribers become many of our biggest advocates because they actually vote for city council members and Metro council leaders making these decisions about farmland preservation" (F4). The social capital generated through the repeated transactions in the form of trust and reciprocity creates the opportunity for an individual to pursue what they believe in. In other words, the social bonds of community and trust often used to characterize local food networks create the social capital needed to help preserve agricultural lands. As one farmer further notes, "I think that people who have a relationship with their farmer and are purchasing food locally increases the political will of individuals to preserve the agrarian lifestyle" (F7). The production-consumption link, thus, plays an active role in creating the countryside. 
Authenticity and Creating the Countryside

Farmers exercise a significant role in creating the countryside, a countryside that helps give Washington County its sense of place. The county has 127,984 acres in farmland, and although local food sold through alternative venues represents a very small percentage of that acreage it is a very public and visible part of Washington County's agricultural landscape. In this section I further explore farmer comments about their land-uses and land-use ideologies to understand the motivations of farmers to participate in local food networks. Authenticity becomes a key theme in helping to explain farmer and consumer activities. I also discuss comments that show the shift of the agricultural landscape to landscape consumption not production. Finally, I highlight how farmers mediate amenity and production activities on their farm and the farmers' role restoring and producing nature.

\section{Motivations}

The farmers' new social role is in the production of food, landscape, rural culture, and fulfilling their idealized image of farm life. The idealized image of farm life can come in the form advertisements, popular culture and as one farmer notes through the stories people are told as children:

When you're little and get read books, the books people get read are about farms and farm animals like the cow and the pig and it's all this perfect little farm. There's the farmer going to collect his eggs and it's all just so cutesy. I think that in some ways and because there is mostly industrial agriculture right now that our culture is striving for those cutesy farm days when you used to 
be able to go out to grandma's house and get some fresh milk or whatever (F5).

The farmers also see themselves as contributing to the sustainability culture of Portland and part of the reason why people find the region attractive. "Overall, I think Portland has a culture of sustainability and caring for the environment, and something easy to do is "buy local"' (F5). One farmer goes further to say that not only do small-scale farms like hers contribute to the sustainability culture of Portland but is also part of the reason why creative people move to region, "I'm sure local food and food in Portland is part of what attracts creative people to Portland. We contribute to the culture that makes the whole region attractive to creative people" (F1).

For many of the new farmers the simplicity of country life is conceptualized as authenticity. By this I mean living in the country becomes a more "natural" way of life for the lifestyle farmers entering into local food networks. Authenticity becomes a key rational because it refers not only to the escape for the "good life" but also the experience of the countryside. Through the farmers new social roles in local food networks they are creating their own version of an authentic landscape and selling the experience of an authentic agricultural lifestyle to the consumer. The hope is to connect people to their farm by giving them an "authentic" experience and through these experiences the agricultural landscape becomes valued by various groups:

I think half the reason our CSA is so successful is because people have a direct link to this farm. They are welcome to come out and stand and dig in the soil. They just want us to be successful 
out here and keep this farm going. We send out newsletters. They consider it their farm too and they are saving a little piece of green out here in Washington County (F2).

One mode farmers use to provide the experience of farm life and rural living is through school programs that expose school children to farm life. Many of the farmers take part in these programs and value them for their educational purposes and as a method to connect children to the site of food production.

Some farmers also throw parties where they invite the school children taking part in their program and their CSA subscription holders. These parties provide subscribers the opportunity to show their friends the farm they subscribe to, but it also gives the farmers the opportunity to market themselves. Leora Davis has built a separate building for her farm events and invites dancers and entertainers to the parties:

You would not believe the party I just had here. It was full of these kids and their families with the kids showing off their farm to their parents. It was a great showing. We had dancers. People were connecting. Many people who were members also brought up to six other friends and said we want to show you our farm; we want to show you what it means to eat locally, and live locally (F4).

The other type of party many of the farmers throw involve ways of preparing or preserving the food given to them in their CSA basket. This type of party is meant to give consumers the chance to exchange recipes and learn how to cook or preserve all of the food given to them in their share, especially later in the growing season when the surplus produce begins to add up. 
Planting and volunteer events are also popular with many of the farmers.

Some farmers try and have an event every month during the warmer months to allow customers the opportunity to experience a little bit of farm life and have a relationship with the land their food comes from by planting tomatoes or harvesting potatoes. The volunteer events are popular with some farmers and as Andrew points out, the volunteers tend to be young people in their twenties with a passion to learn about where their food comes from and how to grow it. His comment is illustrative because it not only shows how the farms are reaching out to give people a part of the farm experience, but it also shows a desire for a younger generation to seek out farm life.

Volunteer days, however, are not successful for all farms. Some farmers do not like, or want, volunteers or interns because it costs them too much in time to train them. Volunteer days can also be a bust, with people just wanting to come out to the farm to see it and not work in the fields. One farmer describes her experience with volunteers:

We opened up a volunteer day and everyone was going to harvest garlic. Two people showed up. One [person] dug and the other watched. We set aside a whole day and it didn't happen. Our group just really wants to eat local and not dig in the soil. We do get a lot of emails about people wanting to spend the day out here. Sure if they want to, but it's not a volunteer farm $(\mathrm{F} 2)$.

The difference between the two experiences is important because it further highlights the differences between the farms and farmers participating in local food networks and the differences between consumers. Many of the most successful 
farms have many on-site amenities such as pizza ovens, separate buildings for entertaining, courtyards, benches, and features that showcase their efforts to create a more sustainable farm such as solar panels, rain-barrels, and other features. Other farms with successful volunteer days also have the benefits of having a full-time farm manager to train and manage volunteer and intern activities. It demonstrates how the abilities of certain farmers to provide the amenities that creates the experience of an authentic farm rather than having origins as a working family farm that is vital to the success of the farm. This shows how the agricultural landscape is in many ways shifting from a landscape of production to a landscape of leisure and consumption.

\section{Landscape of Consumption}

Many of the farmers appear to be moving to the countryside for amenity reasons, but consumers are also increasingly seeking part of the farm experience themselves and a way to reconnect with the land. The connection to the land is something that farmers and consumers feel is lost in the current industrial food system and the desire for people to reconnect with the land is seen as factor in the growth of the local food movement as one farmer notes:

I think the growth in CSAs and local food has to do with a spiritual sense that people have lost a connection to the land. People are searching for a way to reconnect with the land but are not able to actually do that themselves. They move to the country and start their own farm and that sort of thing. So it's a way for them to have a connection to the land (F7). 
The increasing number of people moving to the urban-rural fringe or to the countryside for amenity reasons presents an opportunity for many farmers who produce local foods for local food networks. The divisive issue, however, is when the residents perceive the agricultural landscape as nature and do not realize that the farms are actual working landscapes. People who come to the countryside for leisure or to be 'gentlemen farmers' do not always realize the boundaries and many of the farmers do not want strangers walking through their fields or letting their pets run loose. One farmer illustrates the challenges and opportunities he experiences as people move closer to farmlands and more development occurs along the urban-rural fringe:

We thought if worse comes to worse and there are 40 houses down there and 40 houses down there, we'll just sell those folks vegetables. We are worried about trespassing though because generally city folk don't realize the boundaries out here. We don't want people tramping through our fields. People are harder to contain than animals. We can't keep golfers out of our fields so no way we could keep neighbors out of them (F2).

Pets are also a problem for farmers living close to residential developments and cause some tensions between urban residents and farmers. Residents forget that their pets may pose a problem for farmers with livestock and may not realize that they are moving out to a working landscape. Dogs can harass livestock or as one farmer notes kill a significant amount of their livestock:

I have lost a hundred birds to a domestic dog. I didn't catch the dog so I don't know who it belonged to. In all likelihood it's just somebody who let their dog out to go to the bathroom and never thought it could create a problem for a farmer with livestock. But I mean, dogs...still have the predator instinct, but because they're not hungry they don't have a way to satiate that instinct. 
In my case, they came and they kill, and they kill, and they kill, which is why they killed 100 birds in one night. Even though I have a coyote on the property I have way more problems with a domestic dog (F7).

The farmer goes on to discuss the lack of understanding between people seeking the farm experience and the realities of farm work. People who have no farm experience often approach her about volunteering in exchange for food. She cannot accommodate those requests because training a volunteer often costs more in time than what is given back to her. People also approach her with the idea that working on the farm is leisurely or as a place to bring their kids and let them run free while they work:

Just two weeks ago I had someone come to the farm ostensibly to find out about becoming a CSA shareholder. After I did the tour with her she told me that she was really looking for a place to do a work trade [where she could] bring her three year old.... Of course I told her thank you, but no thank you. I'm not here to baby sit three year olds. This is a working farm (F7).

\section{Amenity Production}

The farmers also try and balance both amenity and farm production. Most see amenity production and farm production as one in the same. However, many of the farmers take part in place-making activities that fit a particular vision of what farm life is and should be about. The place making activities involve creating a beautiful farm setting and a place to experience the beauty of farm life. Activities include planting flowers alongside vegetables, creating courtyards, and erecting compost stations, rain barrels, and solar panels as symbols of their sustainability. 
The amenity production activities are often geared towards visitors, passersby, and for the farmers' own pleasure. As place-making activities farm, they create landscapes that are deliberately in contrast to the landscape of industrial agriculture:

We plant a beautiful herb garden lined with box plantings. I grow flowers because I love flowers. When you go out and see our fields and you see a flower here and a flower there. What is it doing there? It's just there. My husband and I like to plant lettuce red, green, red, green, just so you can see how beautiful it looks. I love to stand in our barn and just see the rows of different shades of greens and textures. I also add flowers to it. It is beautiful. One of those big monocultures though is not beautiful. But when you have a bunch of mixed crops, and you look out it's beautiful (F4).

The beauty of the small-scale farm landscape and the amenity production activities create an identity for the farm but are also used to claim a right to space, a right to space that is in some sense rooted in the American psyche. This helps explain, in part, the desire to protect and preserve the agricultural landscape from the pressures of urbanization. Here the charm and idyllic nature of farm life is marketed by the farmer as an authentic landscape to be consumed by the people coming to the farm, but also to legitimize their right to preserve their place from urban development.

Leora Davis uses the charm and idyllic nature of her farm to make these claims:

This is a beautiful, idyllic place. I would say $90 \%$ of the people who come here say they want to live like this. They don't know how much work it is, but they come out to get a break from the city. They get to see where their vegetables are grown. There are animals and all of that stuff. It is beautiful in itself. It allows people to come out here and have a complete break. Our orchard is gorgeous when it is in bloom, when the fruit is there, the buzzing of the bees. People can have picnics there. They can bring their kids and let them roam free. That's what you miss in 
the city. You can't run free in the city. The close in nature. We are right down the road from Portland. You come out here and feel like you are completely out in the country even though the UGB is $1 / 4$ mile away. This is an amazing place. If it were surrounded by houses it would be a different environment and a different place. It would not have its charm. It would be destroyed (F4).

\section{Producing Habitat and Nature}

An overlooked role many farmers participating in local food networks have is in restoring nature and habitat. "We nurture the soil, we preserve the environment, and we are sustainable (F4)," is a common response when asked to describe land management practices. The regeneration of the soil and drip irrigation is a point of reference for all of the farmers, but they also actively seek to preserve the surrounding environment and wildlife and restore degraded plots. The ideals professed by the farmers fit closely with Altieri's (1995) definition of agroecology, as an agriculture that focuses beyond production to include ecological sustainability in the production process and looks at the crop field as part of the larger ecosystem. Farmers, in this manner, preserve or maintain the environment through composting, using cover crops, protecting and providing habitat for wildlife, planting trees and native species, and eliminating invasive species.

Farmers participating in local food networks actively seek to care for the environment by avoiding chemical inputs on their property by composting and using cover crops. This strategy is important to farmers because it eliminates a major cause of non-point source pollution and reassures farmers that they are not 
putting anything toxic into the watershed. Leora and her husband compost, use drip irrigation, and cover crops to prevent runoff:

It is important to me not to put anything in my soil that is toxic or will run off into the watershed....We try and compost our manure. We use drip irrigation, we tend our soil, use cover crops, we compost, and overall we try not to have runoff $(\mathrm{F} 4)$.

Vicki and her husband have a creek and two wetlands that receive polluted run-off from neighbors. They feel an obligation to keep their property as clean as possible and to do their part in protecting the surrounding environment. The biggest polluter for them is the adjacent golf course that drains into their properties lowlands. The contamination of water on their property is so bad that they entered a government program to help them plant 2,000 trees and help them leach the chemicals out of the soil and water. They also do their part by keeping grass along their drainage area to help capture anything that might escape their property, take special care of their compost and animal manure, and make sure that the property is in good order for the customers who may come to the property to visit.

Protecting wildlife is a point of reference when asked about land management practices on their property. "We feel like part of our responsibility is to protect the wildlife here and to keep the pond healthy" (F2). Wildlife is also important for other reasons on the farm such as rodent and pest control. Farmers working in local food networks try to find ways to provide habitat for animals that can help them on the farm. Vicky wraps poles and builds bird houses on her farm:

We have plenty of trees and wetlands and wildlife. Wildlife is important here, coyotes help us with rodent control, as do red tail hawks. We wrap our poles for red tail hawks and now we have 
another pair of red tail hawks working the fields. We also put up 200 bird houses for the swallows to help us with the insect problem (F2).

When farmers take over formerly degraded plots they also serve a vital role in regenerating the soil and addressing the problems of invasive plant species.

The property has weed problems and problems with invasive species. I have addressed those issues and help make the property more valuable for the landlord. The soil has been worn down and I am working on that issue as well. I also take part in a program to maintain the stream through the property that provides salmon habitat. I try the best I can to restore the land to its natural habitat (F7).

Farmers' actions to address soil degradation, protect wildlife, or replant native vegetation on small-scale farm plots close-in to cities are important for understanding the ecological impacts associated with them, as well as the political impacts of the diverse set of land managers along the urban-rural fringe. Farmers who move to the urban-rural fringe for the rural amenities and produce their own 'idylic' version of the countryside will have different political responses to urban growth. They should be understood as different than the commercial farmer, the nursery farmer, vintner, or even "back-to-the-land" farmer who all may occupy land close-in to cities, but have different aspirations for growth and development along the urban-rural fringe. 


\section{CHAPTER 6}

\section{DISCUSSION AND CONCLUSIONS}

Consumers, merchants, producers, planners, and politicians are all involved in giving meaning to local food and the landscapes that produce it. However, the meanings and benefits of producing locally are not distributed evenly nor do they guarantee that one's farm and livelihood will be saved from an "encroaching metropolis." Rather planners and politicians have to grapple with the ways to balance environmental, economic, and social equity and the conflicts that arise from it. The conclusion is that food sold through local food networks can be used as a means to preserve and develop specific and manageable farm sites and agricultural landscapes but the impact is limited. Large scale impacts on agricultural landscapes and livelihoods depends on the planners and advocates who support policies that recognize a diversity of opinions and land managers, and understanding how local food networks sustain both urban and rural systems.

Situating local food is a complex process that involves defining local food based upon a plurality of consumer definitions and understandings of local food and a spectrum of food production practices. Local food is not defined as separate

from the globalized or conventional food system; rather it is part of it, a response to the dissatisfactions of the current food provisioning system. Furthermore, the plurality of definitions allows local food to be about any number of issues from a better environment to social justice. Shopping locally presents a "confusing landscape of meaning around the word local that consumers feel they must 
negotiate" (Blake, Mellor, and Crane, 2010, 410). The choices can be said to be based on trends toward "sustainable" or "green" consumption habits. However, many of these consumer choices are perceived to link the consumer "back to the land" and provide part of the farm experience through consumption habits.

Participants in a local food network anticipated that through their consumption habits the small-scale farm can be protected from urbanization and made viable.

The farmers participating in local food networks also face a number of issues that affect daily life on the farm. The experiences of farmers, however, are uneven and not shared equally amongst all farmers in local food networks. The divide is most dramatic between the long-standing family farmers who converted to selling locally and the "hobby" or "lifestyle" farmers who began farming based on a desire to live in the country. Regardless of the type of farmer, the farm practices are informed by ideals of social and ecological sustainability, but the farmers face high labor demands, time constraints, and concerns over the planning issues that affect their livelihoods.

Results from the study show that both farmer production and consumer practices are informed by an "authentic" agrarian idealism, "being green," and "sustainability." Access to both economic and social capital allows for the success of farmers participating in local food networks, but also provides the capacity to take part in certain place making activities that adhere to particular visions of what it means to live in the country. Through place making activities the farmers sell an authentic experience to the customer, but also meet their own ideological beliefs of 
what they consider it means to live in the countryside. In other words, the consumer and producer constitute one another through both the consumption of food and landscape. Consumption of local food and landscape has important political and policy implications for sustainability at the urban and regional planning scales.

\section{Is Food at Stake? Planning and Sustainability Conflicts}

Community supported agriculture (CSA) and direct sales through farmers markets are seen by many as a more sustainable food distribution system and a way to connect urban dwellers with farmers in the nearby countryside (Pollan 2006; Christensen 2010). In Oregon policies have been put in place to protect farmland and natural areas adjacent to urban areas where many of the CSA farms are located. As previously mentioned, the establishment of the UGB in 1979 is the most prominent policy example. More recently is the passage of Senate Bill 1011 in 2007 to protect farms, forests, and natural landscape features from urbanization through the implementation of urban and rural reserves. The bill informs the Making the Greatest Place set of policy and investment decisions for the region that came from the 2040 Growth Concept, and was passed to provide long term planning for farmers and a means to protect lands from development for the next 40-50 years (Metro 2009). CSA farmers hope that they see more rural reserves to buttress their growing industry, but also to protect their livelihoods and way of life. 
The volume of produce and the number families that are fed through

CSA is substantial and farmers interviewed for this study hope that their production is enough to be designated as a rural reserve. Leora Davis, for instance, believes she feeds about 300 people through her 50 shares on 2.2 acres of land. Andrew Johnson's 5 acre farm produces a similar amount of food for their 60 shares, plus a contract with Bon Appétit catering. The largest CSA farm in my study is Vicki Huntley's at about 50 acres of productive farmland. She says that she supports around 810 families through her CSA plus the large number of people who buy her produce at five farmers markets throughout the region. In total 920 shares are supported on 57.2 acres amongst these three farmers. If one assumes the average share feeds three people, 2,760 people are fed on 57.2 acres of land. Farmers like Leora see this production as proof that they need to be protected, and close in to cities through incorporation of their land into rural reserves.

Farmers working close to urban areas, such as Andrew Johnson and Leora Davis, believe the rural reserves have a lot of promise but the process has been flawed in Washington County. Both believe that urban interests are being served in the urban and rural designation processes. Andrew says, "it has always been that way in Washington County. This is the home of Intel, Tektronix, Epson, and all the high tech businesses." In his view the large expansion of urban reserves is to generate more tax revenues through property taxes. Leora also says:

I feel like people who make the decisions about the UGB in Washington County have a very urban centric view. They don't include the rural voice. They don't ask for the farmers opinions. The urban and rural reserves [steering committee] have one spot 
for the farm bureau.... The fact that there seems to be a dichotomy between urban growth and rural land [when] it should be something that you think about together is flawed. How are we going to feed this urban population? Urban and rural work together. It's like thinking that the environment and economic prosperity are two different things when they are [connected].

The farmers' comments point to a number of paradoxes that are common to sustainability conflicts. Balancing economic, environmental, and social equity goals often produce conflicts and contradictory goals. The UGB has been argued as a way to spatially define where urbanization ends and "nature" begins as a means for Portland and the region to market itself as a "green city" (Huber and Currie 2007). Metro also uses rhetoric of sustainability in its guide to Making the Greatest Place (Metro 2009). However, farmers see their work as a viable economic industry and part of the sustainable future of the region. The conflict is over bringing more economic development and people to the region and the need to ensure the economic viability of agriculture, while protecting the landscapes that are valued for their productive and cultural purposes from urbanization and development. The paradox is the overlooked role of the farmers of the region in creating the landscape that attracts many people to the region, but in the process their way of livelihood becomes threatened from urbanization. As officials seek to preserve agricultural landscapes from urbanization using rhetoric of sustainability and protection of farms and forests some farmers lose their systems of livelihood through their possible removal or re-designation as urban, and the livelihoods of the small-scale farmers providing food for the region and city are overlooked. The 
argument is typical of what Paul Robbins would define as the conservation and control thesis of political ecology where:

Control of resources and landscapes has been wrested from local producer groups through the implementation of efforts to preserve "sustainability," "community," or "nature." In the process, local systems of livelihood, production, and socio-political organization have been disabled by officials or global interests seeking to preserve the "environment." (Robbins, 2004, 14).

The spatial demarcation of the landscape into urban and rural can have adverse affects by marginalizing the concerns of rural residents who want to participate in the planning process. With only one member of the Washington County Farm Bureau as a representative, local farmers who are threatened by urbanization do not feel as though they are represented fairly and wonder how Portland will feed itself without any local food. However, some farmers may want to be incorporated into the urban reserves to sell their land for development, just as some farmers may be placed on the wrong side of line and become urban when they want to remain rural. The land-use debates highlight concerns of farmers who live in contested areas and want to be preserved and be representatives of a rural authenticity but other farmers do not. Rather, "planners, intellectuals, and activists should recognize they cannot represent all local people in all ways; instead, they must enter into a dialogue that recognizes and respects commonalities as well as difference" (Vandergeest and DuPuis, 1996 5). 
Preserving Landscape for Whom?

Concerns over urban growth and farmland preservation highlight the tensions between preservation and development. Given Portland's reputation for successfully curbing urban sprawl and representation of the UGB as part of the regional landscape providing farm and forest lands close to urban centers, there is a need to ask larger questions about what lands need to be preserved, and for whom, in the representation of landscapes (Robbins 2004; Hinrichs 1996).

Participating in a local food network presents farmers with opportunities and challenges. Making a living from season to season and addressing concerns about urban growth and farmland preservation are concerns for most farmers. However, as the landscape continues to shift from a landscape of production to a landscape of consumption, farmers themselves raise important questions about the type of agriculture that can be practiced along the urban-rural fringe and how to make their farms compatible with development. Blowing dust created by large farm equipment and spray from fertilizer and pesticide application are some of the biggest problems when farms and residential development are in close proximity:

When you build houses too close to farms especially conventional farms where they do a lot of spraying you have problems. The spray blows across the street and there are problems. Most farmer are very conscientious of this and don't spray on windy days, but it's still in the air and bothers some people. When it's harvest time people can be out all night long harvesting...It's hard to remain close to the city or part of the city and you have to be careful. The industrial model is not suited to that, but the small-scale organic model is...I think it is possible for the small scale organic model to work close-in and around development but not the industrial model with pesticides 
and fertilizer being sprayed. That is not compatible with urban neighbors (F3).

Other farmers elaborate this point to also include farms growing niche products such as wine grapes and hazelnuts. Carol Simpson notes, it is a constant struggle to balance the production aspects of farm life with the amenity migrants seeking to be "gentlemen farmers:"

We farm organically but the hazelnut orchard across the street does not, [and] spray can come onto our farm. I know... a lot of the vineyards use propane canons to scare off birds and stuff like that. So they're always trying to balance with people who just want to live out in the country and be gentlemen farmers and not really do stuff and then there are the actual working farms (F5).

The comments highlight the need to better understand how amenity migrants change the landscape, whether they are "gentlemen farmers" looking for a nice place to live in the countryside and become farmers participating in local food networks, or long time family farmers who convert to sell locally. The farmers create an experience of the countryside both for themselves and for the consumers who can then become stakeholders in preserving the agricultural landscape. One farmer hopes this is the case and that he will not continue to see more farms exist in name only as the region seeks to attract more high tech industry:

Well, there are certainly acres and acres of things that have Intel signs on them that say things like Romler Acres and Hawthorne Farms, and Imbrie Farm. You know all of those names. Yeah, there's a big Fred Meyer at Imbrie Farms now. They didn't pick those names because they sounded quaint. Those were the names of the farms that have gone away. All of those farms are gone. We see farms go away [to be] replaced by houses and asphalt and office buildings (F3). 
However, what the farmers comments fail to clearly point out is who benefits and who loses from the various land-use and preservation measures in Oregon. The people living in Oregon who value the rural charm of the countryside and the rural in-migrants lucky enough to purchase a scenic place in the country clearly benefit and do not want to see more farms and scenic areas replaced with office buildings and development. Furthermore, with the case of many of the more recent farmers who moved to the countryside, in large part, for the rural amenities, it is questionable whether they could participate in a local food network without a second income. Rather the benefits of participating in a local food network are not equal and are unevenly distributed amongst people participating in local food networks and residing in rural areas.

On the other end of the spectrum, many Oregonians have no direct stake in the preservation of farmlands or the environment. Large retail chains and the prospect of more urban development represent jobs and basic affordable goods in a state with a high unemployment rate (10.6\%) (BLS 2010). Not all rural residents are able to participate in local food networks and grow specialty foods to be sold through CSAs or farmers markets in the region. In addition, $15.9 \%$ of the state's rural population is in poverty (USDA: ERS State Facts 2010), and many of the farmers who want to grow specialty foods locally cannot participate due to access to capital, land, and other constraints.

Preserving the landscape also allows the regional planning agency, Metro, to set the policies that make the Portland region able to market itself as a uniquely 
'green city' that has balanced the contrasting link between what is considered urban and what is considered natural (Huber and Currie, 2007). Nearly all sections of the population are implicated in the legacy, promotion, and marketing of the region as a uniquely "green" whether it is through the consumption of local food or the jobs and people that are attracted to the region, however the benefits are unevenly distributed. The image of Portland as close to nature remains important to attract new services and labor (cf. Florida, 2005), but also increases the pressure to preserve what is uniquely Oregon: " a lifestyle, economy, and culture that is deeply rooted in the environment" (Metro 2000). To continue to be successful, certain land uses need to be controlled while other land-uses and activities are promoted. The result may be a city that successfully balances urban and rural landuses and provides a green lifestyle through the consumption of local food and the environment, but underneath will be the difficult conflicts over competing visions of land-use and landscape.

\section{Concluding Remarks}

Washington County, as part of the Portland region, provided a useful case study for understanding competing visions of land-use in the context of local food networks. In this case study I have drawn attention to the political and cultural interests that contribute to the emergence and development of local food networks. Jarosz's (2008) study conceptualized local food networks as the product of the political, cultural, and historical processes and interactions between rural 
restructuring and urbanization. My study also contributed to recent debates about the relevance of particular sites and places in understanding local food networks that "captures the importance of place and the diversity of rural and urban interests invested in developing AFNs [alternative food networks], and avoids an essentialized view of "local place"” (Harris, 2010, 366). I demonstrated how ideas of nature and the countryside inform both consumer desires to purchase local products and how images of nature and the countryside inform and motivate people to become farmers participating in local food networks. Those same images of nature can become drivers of conservation policies that can paradoxically threaten and enable farmer livelihoods.

This study also shows how the spaces of farmlands, as places of both production and consumption, become valued for their associated meanings, in particular those of an "authentic" countryside. This follows the interpretation that place is a location made meaningful (Cresswell, 2004, 7). In food studies, "place matters to the consumption practices of individuals and groups in ways that are more important than just location" (Blake, Mellor, and Crane, 2010, 424). The diversity of meanings associated with local food as well as the places those food choices inspire all matter. However, the fact that farmlands have been made meaningful in the consumption of local food can result in policies that lead to the preservation local farms.

Other studies on the "New West" that focus on "struggles that pits open spaces valued for social and ecological reasons against growth and development" 
(Travis 2007, 7), and exurban amenity production (Cadieux 2006) show similar parallels. Walker and Fortmann (2003) for instance, researched how ideas of landscape become politicized and shaped the outcomes of debates on the ways the landscape 'should' look like. Such arguments and analysis are important in places like Oregon where the landscape is highly valued for its amenity purposes in pastoral rural areas with a history of production-oriented economies.

Finally, at the urban and regional planning scales, balancing urban-growth controls, farm production, and amenities at the urban-rural fringe is a complex process. Further research with a more extensive population of people living in exurban areas and along the urban-rural fringe such as vintners, nursery farmers, and industrial/commercial farmers, and residents would enrich this study and make for more informed planning at the urban-rural fringe. However, I want to point towards the idea of planning for the networks that flow into and out of the city uniting the city and the countryside. If, as Cronon (1991) suggests, the countryside is shaped by the networks of goods and people that flow into and out of the city, the policies and measures that are put in place to protect the countryside and natural areas need to reflect the existing networks and links between urban and rural populations and important ecologies both within the city and outside of it. Critical geographers take Cronon's idea more radically, and suggest a politics of the urban metabolism (Heynen, Kaika, and Swyngedouw, 2006). An understanding that cities are linked to local and distant places and ecosystems through their metabolic relationship to nature and society, or that, "urbanization occurs in and through a 
vast network of relationships, and within complex flows of energy and matter, as well as capital, commodities, people and ideas, that link urban natures with distant sites and distant ecologies" (Braun, 2005, 637). This would not only protect the valued natural places that are threatened by urbanization (Huber and Currie, 2007), but it could also avoid a broad single view of 'local' by identifying the diversity of farmers and consumers participating in a local food network and not attribute a single definition or meaning to 'local' food. Rather this way of thinking could capture the array of urban and rural interests in the formation of local food networks, preserve close-in agricultural spaces, and perhaps provide alternative land-uses that reflect the city's and region's sustainability goals and moderate the patterns of sprawl. This confirms that by breaking down the false divides that Cronon (1991) suggests, a better local food system can be created that encompasses a broad vision of the local food economy that addresses both urban and rural concerns from food access to farmland preservation. 


\section{REFERENCES CITED}

Abbott, C. 2001. Greater Portland: Urban Life and Landscape in the Pacific Northwest. Philadelphia, PA: University of Pennsylvania Press.

Abbott, C. and J. Margheim. 2008. Imagining Portland's Urban Growth Boundary: Planning Regulation as Cultural Icon. Journal of the American Planning Association 74: 196-208.

AEA Technology. 2005. The Validity of Food Miles as an Indicator of Sustainable Development. Report to Defra, HMSO, London.

Allen, P., M. FitzSimmons, M. Goodman, and K. Warner. 2003. Shifting plates in the agrifood landscape: the tectonics of alternative agrifood initiatives in California. Journal of Rural Studies 19: 61-75.

Altieri, M. A. 1995. Agroecology: The Science of Sustainable Agriculture. Boulder: Westview.

Beaverton Farmers Market. 2010. Our Growers. http://www.beavertonfarmersmarket.com/Growers.aspx. (last accessed 24 June 2010).

Blake, M. K., J. Mellor, and L. Crane. 2010. Buying Local Food: Shopping Practices, Place, and Consumption Networks in Defining Food as "Local." Annals of The Association of American Geographers 100: 409-426.

Blay-Palmer, A. and B. Donald. 2006. A Tale of Three Tomatoes: The New Food Economy in Toronto, Canada. Economic Geography 82: 383-399.

BLS (Bureau Labor Statistics). 2010. Local Area Unemployment Statistics: Unemployment Rates for States, Seasonally Adjusted Mar. 2010. http://www.bls.gov/web/laus/laumstrk.htm. (last accessed 4 May 2010).

Bradley, K. and J. Bradley (F1). 2009. Interview by author. Washington County, OR. October 9.

Braun, B. 2005. Environmental issues: writing a more-than-human urban geography. Progress in Human Geography 29: 635-650.

Bryant, R. L. and M. K. Goodman. 2004. Consuming narratives: The political ecology of "alternative" consumption. Transactions of the Institute of British Geographers 29: 344-366. 
Cadieux, K. V. 2006. Productive and Amenity Relationships with Exurban Nature: Engagement and Disengagement in Urban Agriculture and the Residential Forest. PhD diss., University of Toronto.

Carson, R. 1962. Silent Spring, First Mariner Books Edition 2002. Houghton Mifflin Company: New York.

Christensen, N. 2010. Food at Stake? The Hillsboro Argus 2 February.

Coley, D., M. Howard, and M. Winter. 2009. Local food, food miles and carbon emissions: A comparison of farm shop and mass distribution approaches. Food Policy 34: 150-155.

Cresswell, T. 2004. Place: a short introduction. Malden, MA: Blackwell Publishing.

Cronon, W. 1991. Nature's Metropolis: Chicago and the Great West. New York: W.W. Norton \& Company, Inc

Davis, L. (F4). 2009. Interview by author. Washington County, OR. October 22.

DuPuis, E. M. 2006. Landscapes of Desires. In Handbook of Rural Studies, ed. by P. Cloke, T. Marsden, and P. H. Mooney, 124-132. London: Sage Publications.

Feagan, R. 2007. The place of food: mapping out the 'local' in local food systems. Progress in Human Geography 31: 23-42.

Feenstra, G. 1997. Local food systems and sustainable communities. American Journal of Alternative Agriculture 12: 28-36.

Fitzsimmons, M. 1989. The matter of nature. Antipode 21: 106-120.

Florida, R. 2005. Cities and the Creative Class. New York: Routledge.

Forest Grove Farmers Market. http://www.adelantemujeres.org/farmersmarket.html. (last accessed 24 June 2010).

Gilg, A., S. Barr, N. Ford. 2005. Green consumption or sustainable lifestyles? Identifying the sustainable consumer. Futures 37: 481-504.

Glaser, B.G. and A. Strauss. 1967. The discovery of grounded theory: Strategies for qualitative research. Chicago, IL: Aldine Publishing Co. 
Guthman, J. 1998. Regulating meaning, appropriating nature: the codification of California organic agriculture, Antipode 30: 135-154.

---- 2004. Agrarian Dreams: The Paradox of Organic Farming in California. Berkeley: University of California Press.

2008. Neoliberalism and the making of food politics in California. Geoforum 39: 1171-1183.

Goodman, M. 2003. The quality 'turn' and alternative food practices: reflections and agenda. Journal of Rural Studies 19: 1-7.

Goodman, M. and E. M. DuPuis. 2005. Should we go "home" to eat?: toward a reflexive politics of localism. Journal of Rural Studies 21: 359-371

Harris, E. M. 2010. Eat Local? Constructions of Place in Alternative Food Politics. Geography Compass 4: 355-369.

Harvey, T. and M. Works. 2002. Urban Sprawl and Rural Landscapes: perceptions of landscape as amenity in Portland, Oregon. Local Environment 7: 381-396.

Heynen, N., M. Kaika, and E. Swyngeouw. 2006. In the Nature of Cities: Urban political ecology and the politics of urban metabolism. Routledge: London.

Hillsboro Farmers Market. 2010. Vendors. http://www.hillsboromarkets.org/?page_id=33. (last accessed 24 June 2010).

Hinrichs, C. C. 1996. Consuming Images: Making and Marketing Vermont as Distinctive Rural Place, In Creating the Countryside, Ed. P. Vandergeest and E.M. DuPuis, 259-278, Philadelphia: Temple University Press.

2000. Embeddedness and local food systems: notes on two types of direct agricultural market. Journal of Rural Studies 16: 295-303.

Howard, T. (F7). 2009. Interview by author. Washington County, OR. September 15.

Huber, M. T. and T. M. Currie. 2007. The urbanization of an idea: imagining nature through urban growth boundary policy in Portland, Oregon. Urban Geography 28:8 705-731. 
Huntley, V., (F2). 2009. Interview by author. Washington County, OR. October 7.

Jacobsen, S., (F6). 2009. Interview by author. Washington County, OR. October 23.

Jarosz, L. 2000. Understanding agri-food networks as social relations. Agriculture and Human Values 17: 41-55.

---------. 2008. The city in the country: Growing alternative food networks in Metropolitan areas. Journal of Rural Studies 24: 231-244.

Johnson, A. and C. Johnson (F3). Interview by author. Washington County, OR. September 24, 2009.

Kingsolver, B. 2007. Animal, Vegetable, Miracle: A Year of Food Life. HarperCollins: New York.

Kloppenberg, J., J. Henrickson, and G.W. Stevenson. 1996. Coming into the foodshed. Agriculture and Human Values 13: 33-42.

Knapp, G. and A.C. Nelson. 1992. The Regulated Landscape: Lessons on State Land Use Planning from Oregon. Cambridge, MA: Lincoln Institute of Land Policy.

McCarthy, J. 2002. First World political ecology: lessons from the Wise Use movement. Environment and Planning A 34: 1281-1302.

Metro. 2000. The Nature of 2040: The Region's 50-Year Strategy for Managing Growth. Portland, OR: Metro.

------. 2009. A Guide to: Making the Greatest Place. Portland, OR: Metro. http://www.oregonmetro.gov/index.cfm/go/by.web/id=231. (last accessed 8 May 2010).

Mohan G. and J. Mohan. 2002. Placing social capital. Progress in Human Geography. 26: 191-210.

Mortenson, E. 2009. Dust-ups arise as the region's urban-rural line blurs. The Oregonian 6 May. 
Mutersbaugh. T. 2002. The number is the beast: a political economy of organic-coffee certification and producer unionism. Environment and Planning 34: 1165 - 1184.

Pollan, M. 2001. Naturally. New York Times 13 May.

----------. 2006. The Omnivore's Dilemma: a Natural History of Four Meals. Penguin Press: New York.

Portland CSA Coalition. 2008. Fresh food direct from the farm! Canby, OR. http://portlandcsa.org/PACSAC\%20CSA\%20List\%202008.pdf. (last accessed 24 June 2010).

Putnam, R. 1993. Making democracy work: civic traditions in modern Italy. Princeton University Press: Princeton.

Relph, E. 1976. Place and Placelessness. Pion: London.

Robbins, P. 2004. Political Ecology: A Critical Introduction. Blackwell: Oxford.

Robbins, W.G. 2004. Landscapes of Conflict: The Oregon Story, 1940-2000. University of Washington Press: Seattle.

Schlosser, E. 2001. Fast Food Nation: The Dark Side of the All-American Meal. Houghton Mifflin Company: Boston.

Schmidt, B. and E. Suh. 2009. Urban boundary: Figuring out where metro Portland growth will go. The Oregonian 4 April.

Selfa, T. and J. Qazi. 2005. Place, taste, or face-to-face? Understanding producer-consumer networks in "local" food systems in Washington State. Agriculture and Human Values 22: 451-464.

Simpson, C., (F5). 2009. Interview by author. Washington County, OR.September 22.

Smithers, J., J. Lamarche, and A. Joseph. 2008. Unpacking the terms of engagement with local food at the Farmers' Market: Insights from Ontario. Journal of Rural Studies 24: 337-350. 
Starr, A., A. Card, C. Benepe, G. Auld, D. Lamm, K. Smith, and K. Wilken. 2003. Sustaining local agriculture: Barriers and opportunities to direct marketing between farms and restaurants in Colorado. Agriculture and Human Values 20: 301-321.

Suh, E. 2007. Plans for South Hillsboro take shape. The Oregonian 3 December.

Trauger, A. 2009. Social agency and networked spatial relations in sustainable agriculture. Area 41: 117-128

Travis, W.R. 2007. New Geographies of the American West: Land Use and the Changing Patterns of Place. Washington, DC: Island Press.

United States Census Bureau. 2009. State and County Quick facts. $<$ http://quickfacts.census.gov/qfd/states/41/41067.html (last accessed 4 May 2010).

USDA ERS (United States Department of Agriculture, Economic Research Service). 2010. State Fact Sheets: Oregon. http://www.ers.usda.gov/stateFacts/OR.HTM. (last accessed 4 May 2010).

USDA FSA (United States Department of Agriculture, Farm Service Agency). 2009. Fact Sheet: Loans for Beginning Farmers and Ranchers.

USDA NASS (United States Department of Agriculture, National Agricultural Statistics Service). 2007. http://www.agcensus.usda.gov/Publications/2007/index.asp. (last accessed 4 May 2010).

Vandergeest, $\mathrm{P}$ and E.M. DuPuis. 1996. Introduction. In Creating the Countryside, Ed. P. Vandergeest and E.M. DuPuis, 1-25, Philadelphia: Temple University Press.

Vos, T. 2000. Visions of the middle landscape: Organic farming and the politics of nature. Agriculture and Human Values 17: 245-256.

Walker, P. and L. Fortmann. 2003. Whose landscape? A political ecology of the 'exurban' Sierra. Cultural Geographies 10: 469-491.

Watts, D.C.H., B. Ilbery, and D. Maye. 2005. Making reconnections in agro-food geography: alternative systems of food provision. Progress in Human Geography 29: 22-40. 
Whatmore, S. and L. Thorne. 1997. Nourishing Networks: Alternative Geographies of Food. In Globalising Food: Agrarian Questions and Global Restructuring, ed. by D. Goodman and M. Watts, 287-304. Routledge: London.

Works, M. and T. Harvey. 2005. Can the way we eat change metropolitan agriculture? The Portland example. Terrain.org: A journal of the Built and Natural Environments. 


\section{APPENDIX A}

Questions for Semi-Structured Interviews: Farmers Selling Through Farmers Markets or CSAs

What does a local food system mean to you?

What are your biggest concerns about urban growth and farm preservation?

What is your perspective on the emergence and development of alternative food networks?

What role do you think CSAs or farmers markets can have in preserving agricultural lands and livelihoods in Washington County?

What measures do you think should be taken to preserve farmland from urban growth?

Do you think urban demand for local foods can preserve farmland in urbanizing areas?

What were your motivations to become a farmer?

How would you describe you land management practices?

[Usually asked in terms of organic, sustainable, or something else. If I used term ideology it wasn't picked up on the way I wanted. I would usually then switch to something about stewardship and what they're doing with their land and why. The question usually turned into me asking them to explain land related activities and point out particular circumstances.]

What do you do with your property?

How are your farm activities valued for both amenity purposes and productivity?

What is the relationship between your farming/productive activities and amenity projects on your property?

[Amenity usually had to be changed to beautiful.

How do you combine both productivity and 
beautification? This is one example of how this question was changed during the interview.]

How do you think your land-use activities relates to larger political, economic, or environmental problems and solutions?

What are your concerns about Metro's designation of urban and rural reserves?

Are urban or rural interests served in the designation of urban and rural reserves?

Have you noticed any tensions between farmers and urban residents?

Have you received any complaints about your farm activities?

What changes have you noticed in crop production as population has increased in Washington County?

[Usually asked in terms of farm size, distance to city or hobby farms.]

How does selling locally benefit you?

How do you place your activities in larger global and regional processes?

What are your biggest difficulties and challenges participating in an alternative food network?

What kind of buyers work best for you operation? (e.g. Friends, wholesalers, restaurants)

[Or who are your best customers?]

Are you satisfied with your current system of marketing and selling? If not, what changes would you like to see made?

What are the biggest constraints or draw backs to direct marketing?

Do you feel the effects of international competition?

What are the class and ethnic dimensions in local food networks that you have noticed?

What are the benefits of working in a local food system and direct marketing? 
What do you perceive the biggest challenges are to preserving the small scale or family farm? 


\section{APPENDIX B}

Sample Survey for Farmers Selling to Farmers Markets CSAs

What do you produce?

When did you begin farming?

What is the size of your operation?

Is your agricultural enterprise your total income? If not, what other work do you do?

What percentage of your income is generated through farm sales?

What percentage of your sales are:
a. In the state of Oregon?
b. Within 100 miles of your farm?
c. International

How many months of the year do you sell produce?

Are you seeking to expand your markets or are you at full capacity?

Is your operation dependent on interns or apprentices?

Seasonal Workers?

Household labor?

Should consumers have more outlets to buy locally grown produce?
A. Yes
B. No
C. Neutral

How many miles would you travel to sell your produce? 


\section{APPENDIX C}

\section{Interview Questions for Farmers Market Managers}

What does a local food system mean to you?

What is your perspective on the emergence and development of alternative food networks?

What role do you think CSAs or farmers markets can have in preserving agricultural lands and livelihoods in Washington County?

Do you think urban demand for local foods can preserve farmland in urbanizing areas?

Have you noticed any tensions between farmers and urban residents?

What do you perceive the biggest challenges are to preserving the small scale or family farm from urbanization?

Do you think urban demand for local foods can preserve farmland in urbanizing areas?

How does selling locally benefit you?

What are your biggest difficulties and challenges participating in an alternative food network?

What kind of buyers work best for you operation? (e.g. Friends, wholesalers, restaurants)

[Or who are your best customers?] 


\section{APPENDIX D}

\section{Consumer Surveys}

Beaverton (BV). October 3, 2009. FM79-FM78.

Forest Grove (FG). September 23, 2009. FM33-FM74, FM75-FM77.

Hillsboro (HB). September 19, 2009. FM1-FM32.

1. What percentage of your food purchases come from farmers markets or CSAs?
A. Less than $10 \%$
B. $20 \%$
C. $40 \%$
D. $60 \%$
E. $80 \%$ or more

2. How would you define local food?
A. County
B. State
C. Pacific Northwest
D. Less than 100 miles
E. Other, explain

3. How often do you attend farmers markets?
A. Weekly
B. Monthly
C. Less than four times a year

4. On a scale of 1 to 5 rank the importance of the following in order of your decisions to purchase local, 1 being least and 5 most:

The proximity of farms, an effort to reduce 'food miles.'

$\begin{array}{lllllll}\text { Least Important } & 1 & 2 & 3 & 4 & 5 & \text { Most Important }\end{array}$

Taste: You believe the food tastes fresher and is healthier.

$\begin{array}{lllllll}\text { Least Important } & 1 & 2 & 3 & 4 & 5 & \text { Most Important }\end{array}$


Face-to-Face Relationships or Trust: You like to know your farmer and where your food is coming from

$\begin{array}{lllllll}\text { Least Important } & 1 & 2 & 3 & 4 & 5 & \text { Most Important }\end{array}$

Preserve Farm life: You want to support small-scale farmers economically.

$\begin{array}{lllllll}\text { Least Important } & 1 & 2 & 3 & 4 & 5 & \text { Most Important }\end{array}$

Preserve agricultural landscape: You make your decisions based on small-scale farms being more environmentally sustainable than industrial farms or to preserve the cultural landscape.

$\begin{array}{lllllll}\text { Least Important } & 1 & 2 & 3 & 4 & 5 & \text { Most Important }\end{array}$

5. On a scale of 1 to 5 rank the importance of the following in order of your decisions to purchase local, 1 being least and 5 most:

Environmental Impact

$\begin{array}{lllllll}\text { Least Important } & 1 & 2 & 3 & 4 & 5 & \text { Most Important }\end{array}$

Health Concerns

$\begin{array}{lllllll}\text { Least Important } & 1 & 2 & 3 & 4 & 5 & \text { Most Important }\end{array}$

Support Local Economy

$\begin{array}{lllllll}\text { Least Important } & 1 & 2 & 3 & 4 & 5 & \text { Most Important }\end{array}$

Food Safety

$\begin{array}{lllllll}\text { Least Important } & 1 & 2 & 3 & 4 & 5 & \text { Most Important }\end{array}$

Protect farmland from urbanization.

$\begin{array}{lllllll}\text { Least Important } & 1 & 2 & 3 & 4 & 5 & \text { Most Important }\end{array}$

6. Should farmers be offered more venues for direct sales?
a. yes
b. no
c. neutral 
7. Do you believe your food purchases can help preserve the small-scale farm?
a. yes
b. no
c. neutral

8. Should small-scale farms be protected from urban growth?
a. yes
b. no
c. neutral

9. Do you think small scale and/or family farms are an important component to Oregon's landscape?
a. yes
b. no
c. neutral

10. Do you believe Oregon's agricultural landscape is an important part of Oregon's cultural identity?
A. Yes
B. No
C. Neutral

11. What are your perceptions of Oregon's agricultural landscape?

12. Further comments or opinions? 